MAYER, Laura; VERA, Jaime "El documento como objeto material de las falsedades

documentales y del sabotaje informático en el Derecho penal chileno".

Polít. crim. Vol. 14, No 27 (Julio 2019), Art. 12, pp. 419-455

[http://politcrim.com/wp-content/uploads/2019/05/Vol14N27A12.pdf]

\title{
El documento como objeto material de las falsedades documentales y del sabotaje informático en el Derecho penal chileno*
}

\section{The document as a material object of forgery and computer sabotage under the Chilean Criminal Law}

\author{
Laura Mayer Lux \\ Profesora de Derecho penal \\ Pontificia Universidad Católica de Valparaíso \\ laura.mayer@pucv.cl \\ Jaime Vera Vega \\ Profesor de Derecho penal y de Derecho procesal penal \\ Pontificia Universidad Católica de Valparaíso \\ jaime.vera@pucv.cl
}

\section{Resumen}

El presente trabajo analiza el concepto de documento como objeto material de los delitos de falsedades documentales y del sabotaje informático en el Derecho penal chileno. Para ello, comienza examinando la noción de documento, incluyendo al documento electrónico. Luego, estudia el concepto de documento como objeto material de las falsedades documentales. A continuación, aborda la noción de documento como objeto material del sabotaje informático. Finalmente, trata algunos problemas de delimitación entre la falsedad que recae sobre documentos electrónicos y el sabotaje informático.

Palabras clave: funcionalidad documental, funcionalidad informática, propiedad, delito de daños, documento electrónico

\begin{abstract}
This paper analyzes the concept of document as a material object of the crime of forgery and computer sabotage in the Chilean Criminal Law. To do this, it begins by examining the notion of document, including the electronic document. Then, it studies the concept of document as a material object of forgery. Next, it addresses the notion of document as a material object of computer sabotage. Finally, it deals with some problems of delimitation between the forgery that affects electronic documents and the computer sabotage.
\end{abstract}

Key words: documentary functionality, computer functionality, property, property damage, electronic document 
MAYER, Laura; VERA, Jaime "El documento como objeto material de las falsedades documentales y del sabotaje informático en el Derecho penal chileno".

\section{El concepto penal de documento}

\subsection{Aspectos generales del concepto de documento. Especial referencia a su desarrollo en materia de falsedades documentales}

La determinación de aquello que debe considerarse como documento para efectos penales ha estado fuertemente ligada a la dogmática de los delitos de falsedad documental, figuras en que la conducta falsaria debe recaer, precisamente, sobre ese específico objeto material.

Más allá de la concepción de documento que se adopte, no es posible obviar la importancia del documento como medio para establecer vínculos entre los sujetos ${ }^{1}$. En concreto, el documento es producto de la denominada acción documentadora o, simplemente, documentación ${ }^{2}$, que resulta fundamental para el desarrollo de las relaciones jurídicas al interior del tráfico ${ }^{3}$. Tal acción implica la incorporación de un pensamiento o de actos de voluntad a un medio material, generalmente a través de la escrituración o de otros mecanismos que posibiliten su implantación en un soporte, y que dependerán de las características del mismo.

Para la construcción de un concepto jurídico penal de documento debe tenerse presente, en primer lugar, que en las falsedades documentales el documento constituye un elemento normativo del tipo ${ }^{4}$ respecto del que, a diferencia de lo que ocurre en otros ordenamientos jurídicos ${ }^{5}$, el Código Penal chileno no establece una definición ${ }^{6-7}$.

\footnotetext{
* Trabajo redactado en el marco del Proyecto Fondecyt $\mathrm{N}^{\circ} 1161066$ "Los delitos informáticos en el ordenamiento jurídico chileno: análisis dogmático y crítico, y propuestas de lege ferenda".

1 Por esta característica del documento BACIGALUPO, Enrique, "La reforma de las falsedades documentales", La Ley: Revista jurídica española de doctrina, jurisprudencia y bibliografía, $\mathrm{n}^{\circ} 1$ (1996), pp. 1668-1672, p. 1669, recurriendo a la jurisprudencia del Tribunal Supremo español y a un sector de la doctrina alemana, lo concibe como "la corporización de una declaración o manifestación destinadas y apropiadas para probar una relación jurídica, que permite conocer a su emisor".

2 Véase BENÉYTEZ, Luis, "Bien jurídico protegido: Concepto de documento público. Las conductas falsarias del art. 302 del CP", en: Las falsedades documentales. Libro homenaje a Enrique Ruiz Vadillo, Granada: Comares, 1994, pp. 37-76, pp. 45 y ss.

${ }^{3}$ En efecto, la función documentadora aparece en distintos sectores del ordenamiento jurídico, que ponen en evidencia su importancia y justifican el recurso al Derecho penal para brindarle protección. Así, por ejemplo, ella figura en el marco de la función notarial, regulada en nuestro Derecho en los artículos 399 y ss. del Código Orgánico de Tribunales, disposiciones de las cuales se desprende que los notarios tienen el carácter de ministros de fe pública y, como tales, están facultados para crear documentos que hacen fe acerca de determinados hechos que, además, pueden considerarse existentes bajo ciertos supuestos. La documentación se proyecta también con respecto a aquellos funcionarios que se encargan de mantener determinados registros públicos, como conservadores y oficiales del Registro Civil. Asimismo, la función documentadora se expresa en relación con los órganos administrativos, pues sus funcionarios actúan plasmando hechos y manifestando declaraciones de voluntad a través de documentos. En fin, la documentación opera igualmente en el ámbito privado de las relaciones interpersonales, incorporando un contenido ideal en un soporte material. En ese sentido BENÉYTEZ, "Bien jurídico", cit. nota n 2, pp. 45 y ss.

${ }^{4}$ Véase CARRERAS, Eduardo, Los Delitos de Falsedades Documentales, Buenos Aires: Ad-hoc, 1998, p. 50.

${ }^{5}$ Así, por ejemplo, el artículo 26 del Código Penal español prevé un concepto general de documento en los siguientes términos: "A los efectos de este Código se considera documento todo soporte material que exprese o incorpore datos, hechos o narraciones con eficacia probatoria o cualquier otro tipo de relevancia jurídica".
} 


\section{Polít. crim. Vol. 14, N 27 (Julio 2019), Art. 12, pp. 419-455 [http://politcrim.com/wp-content/uploads/2019/05/Vol14N27A12.pdf]}

Para la definición jurídico penal de documento ha de considerarse, en segundo lugar, que la referencia etimológica y lingüística de dicho término pocas luces aporta en relación con lo que debemos entender por tal y, en cierta medida, explica las razones de su ambigüedad.

"Documento" proviene del verbo latino doceo, compuesto por el prefijo do y el indicativo scio, que alude a dar ciencia acerca de algo ${ }^{8}$. De esta raíz surge una de las acepciones de "documento", a saber, dar a conocer algo o expresar algo al exterior". Tal idea se asocia con una concepción amplia ${ }^{10}$, que en general califica como documento a cualquier objeto que ostente dicho atributo.

Sin embargo, la expresión "documento", en su sentido natural y obvio, también refiere a la escritura, instrumento o acta con que se prueba o se hace constar alguna cosa, significado que se relaciona con una visión más restringida, pues circunscribe la realidad documental sólo a aquella que consta en un soporte capaz de contener una declaración escrita, muy especialmente cuando se trata del papel ${ }^{11}$.

Pues bien, a fin de plantear una definición alternativa del concepto de documento desde una perspectiva jurídico penal, puede partirse del bien jurídico protegido por los delitos de falsedad documental. A nuestro juicio, el interés tutelado por dichos delitos está constituido por la triple funcionalidad documental, esto es, la función de perpetuación, de garantía y de prueba de los documentos, funciones de las cuales es posible deducir los elementos que deben estar presentes para considerar a un objeto como documento ${ }^{12}$.

De la función de perpetuación, entendida como el registro perdurable de una determinada declaración, se desprende que el documento es esencialmente un soporte material que, como tal, fija una declaración del pensamiento humano ${ }^{13}$. Por esto se afirma que el

\footnotetext{
${ }^{6}$ Aunque, como afirma BENÉYTEZ, "Bien jurídico", cit. nota n 2, p. 47, la ausencia de un concepto legal de documento no constituye necesariamente un aspecto criticable, pues el Derecho penal, como instrumento de protección, opera sobre una realidad objetivada y delimitada por otros sectores del ordenamiento jurídico.

${ }^{7}$ En todo caso, no debe extrañar la falta de un concepto de documento en nuestro Código Penal, pues ésta era la tendencia en los ordenamientos que constituían una referencia a la época de su dictación. En ese sentido, no existió una definición de documento en el Code de 1810, el que ni siquiera utilizó tal expresión, sino que aludía a los "escritos". La misma situación se produjo en los Códigos Penales de Italia de los años 1889 y 1930, en todos los Códigos españoles previos al Código de 1995, e incluso en el StGB de 1871, al menos en su versión original. Estos cuerpos normativos se contentaron, como en nuestro caso, con una simple enumeración de los objetos materiales sobre los que podía recaer la falsedad. Véase ETCHEBERRY, Alfredo, "El objeto material del delito de falsedad documental: documentos y sus clases", Revista de Ciencias Penales, tomo XX (1961), pp. 219-240, p. 219.

${ }^{8}$ VILLACAMPA, Carolina, La falsedad documental: análisis jurídico penal, Barcelona: Cedecs, 1999, p. 98.

${ }^{9}$ Véase GARCÍA, María del Carmen, Falsedades documentales (en el Código Penal de 1995), Valencia: Tirant lo blanch, 1997, p. 51.

${ }^{10}$ Véase infra, en este mismo apartado.

${ }^{11}$ Véase VILLACAMPA, La falsedad, cit. nota ${ }^{\circ}$ 8, p. 98.

${ }^{12}$ En esa dirección GARCÍA, Falsedades, cit. nota ${ }^{\circ} 9$, pp. 45 y ss.

13 Véase, por ejemplo, BACIGALUPO, Enrique, "Documentos electrónicos y delitos de falsedad documental", Revista Electrónica de Ciencia Penal y Criminología, 04-12 (2002), pp. 1-17, p. 3, quien destaca que la función de perpetuación también permite que el documento sea cognoscible por personas distintas de su emisor.
} 


\section{MAYER, Laura; VERA, Jaime "El documento como objeto material de las falsedades documentales y del sabotaje informático en el Derecho penal chileno".}

documento, para efectos penales, es en realidad el resultado de combinar un soporte material y datos, hechos o narraciones procedentes de una declaración de conocimiento o voluntad $^{14}$, de modo que ambos aspectos deben considerarse como un todo. A raíz de lo señalado, desde el punto de vista de la función de perpetuación, surgen dos elementos del concepto penal de documento: uno material, referido al soporte; y otro de fondo, concerniente al contenido ${ }^{15}$.

De la función de garantía, esto es, aquella que permite la recognoscibilidad de su autor ${ }^{16}$, se colige el tercer elemento del concepto de documento: en todo soporte que se califique de tal debe existir un autor, que está tras la declaración contenida en dicho soporte y al cual puede imputársele el contenido de la misma.

Finalmente, de la función probatoria, entendida como la aptitud de demostrar (procesalmente) la existencia de una determinada declaración ${ }^{17}$, se desprende la necesidad de que el documento tenga incidencia en el tráfico jurídico, sea que se trate de una eficacia probatoria en sentido estricto o de una relevancia jurídica más amplia ${ }^{18}$.

La exigencia de una cierta perdurabilidad, que involucra la función de perpetuación, impide, por ejemplo, considerar como documentos a las declaraciones realizadas en la arena o en la nieve, pues en tales casos no se garantiza una permanencia en el tiempo de su contenido $^{19}$. Este requisito, que permite distinguir al documento de la declaración oral, sólo impone una cierta fijeza temporal, no así una indestructibilidad o subsistencia eterna de dicho contenido, bastando con que éste tenga un carácter indeleble ${ }^{20}$.

Los mayores inconvenientes que genera el concepto de documento no pasan por el aspecto indicado, sino que por la necesidad o no de que dicho soporte se identifique con un (papel) escrito. A partir de ello se plantea una separación entre concepciones documentales restringidas y amplias ${ }^{21-22}$. Para las primeras, documento es aquel soporte materializado en

${ }^{14}$ QUERALT, Joan, "La falsedad documental: una aporía casacional”, en: LÓPEZ, Jacobo; ZUGALDÍA, José (coords.), Dogmática y ley penal. Libro homenaje a Enrique Bacigalupo, tomo II, Barcelona: Marcial Pons, 2004, pp. 1121-1152, p. 1127.

${ }^{15}$ En virtud de estos dos elementos que surgen de la función perpetuadora, es que autores como CASAS, Enrique, El delito de falsedad en documento privado, Barcelona: Bosch, 1984, pp. 237 y s. también plantean una distinción entre los conceptos de "documento" y de "acto", correspondiendo al primero la calidad de continente y al segundo la calidad de contenido.

${ }^{16}$ En ese sentido GARCÍA, Falsedades, cit. nota n ${ }^{\circ}$ 9, p. 42; también ARMENTEROS, Miguel, Los delitos de falsedad documental, Granada: Comares, 2011, p. 42.

${ }_{17}^{17}$ Véase, por ejemplo, BACIGALUPO, Enrique, "Documentos electrónicos", cit. nota n 13, p. 3.

${ }^{18}$ Los elementos del concepto penal de documento, con excepción de la referencia al autor, cuentan con pleno reconocimiento en la definición prevista en el artículo 26 del Código Penal español, que fuera citada. Asimismo, en la doctrina penal alemana se reconoce un concepto de documento que los considera a todos ellos. Véase solamente FISCHER, Thomas, Strafgesetzbuch und Nebengesetze, 64ª edición, München: Beck, 2017, § 267, nm. 2.

${ }^{19}$ Véase GARCÍA, Falsedades, cit. nota n ${ }^{\circ}$ 9, p. 64; VILLACAMPA, La falsedad, cit. nota ${ }^{\circ}$ 8, p. 102.

${ }^{20}$ QUERALT, "La falsedad", cit. nota ${ }^{\circ} 14$, p. 1128.

${ }^{21}$ Sobre tales concepciones véase, por ejemplo, CANELO, Carola, et al., "El documento electrónico. Aspectos procesales", Revista Chilena de Derecho Informático, nº 4 (2004), pp. 81-106, p. 84.

${ }^{22}$ Algunos llaman concepción latina a la postura restringida y concepción germánica a la postura amplia. En este orden de ideas CALLE, María Victoria, "Teoría general sobre la falsedad documental y selección de 


\section{Polít. crim. Vol. 14, № 27 (Julio 2019), Art. 12, pp. 419-455 [http://politcrim.com/wp-content/uploads/2019/05/Vol14N27A12.pdf]}

un escrito $^{23}$, pues así se desprende de la regulación civil y procesal, desde la que se ha elaborado una teoría general del documento como medio de prueba que corresponde, justamente, a un soporte escriturado. Para las segundas, en cambio, documento es cualquier soporte capaz de expresar una declaración del pensamiento humano ${ }^{24}$, incluyéndose registros fotográficos, cinematográficos o fonográficos; las radiografías $\mathrm{o}$ los electrocardiogramas; los planos o dibujos; entre otros.

Se trata de una cuestión que no es baladí, si se tiene en cuenta que la exigencia de escrituración excluye del concepto de documento las nuevas formas de expresión del pensamiento humano surgidas con los avances tecnológicos de la segunda mitad del siglo XX y lo que ha transcurrido del siglo XXI, y que van desde las cintas magnetofónicas hoy muy en desuso - hasta los soportes informáticos. Estos objetos no fueron considerados por nuestro legislador al prever las normas extrapenales sobre documentos (como medio de prueba y soporte negocial), ni menos al establecer las normas penales relativas a las falsedades documentales ${ }^{25}$, pero es indudable que en la actualidad desempeñan un papel de enorme importancia dentro del tráfico jurídico.

En el Derecho comparado, las corrientes doctrinales más modernas apuntan a una ampliación del soporte material del documento, con la finalidad de incluir a los objetos aparecidos con motivo del desarrollo tecnológico. En el caso del Derecho penal español, esta tendencia tuvo un reconocimiento legal expreso a partir de la consagración de un concepto amplio de documento, que se contempla en el artículo 26 del Código Penal. A la elaboración de este concepto contribuyó una jurisprudencia que se fue consolidando mediante sucesivas sentencias del Tribunal Supremo ${ }^{26}$. Por su parte, la doctrina española,

jurisprudencia sobre la falsedad documental con especial referencia al documento mercantil, I y II", Cuadernos de Política Criminal, $\mathrm{n}^{\circ} 53$ (1994), pp. 703-740, p. 705. La concepción latina considera como documentos sólo a los escritos, mientras que para la concepción germánica lo decisivo es que el objeto material pueda servir como prueba. La amplitud de la concepción germánica es una cuestión que también se deduce del origen de la palabra Urkunde (documento), que proviene de Ur y Kunde, que significa dato original. Véase CAMARGO, César, "Falsificación de documentos públicos", Anuario de Derecho Penal y Ciencias Penales, $\mathrm{n}^{\circ} 3$ (1957), pp. 519-538, p. 522.

${ }^{23}$ Por todos BINDING, Karl, Lehrbuch des Gemeinen Deutschen Strafrechts, Besonderer Teil, tomo II, $2^{\text {a }}$ edición aumentada, Leipzig: Engelmann, 1904, p. 170.

${ }^{24}$ En esa línea CARNELUTTI, Francesco, Teoria del falso, Padova: Cedam, 1935, p. 138.

${ }^{25}$ Cuestión que también explica que la doctrina más antigua sea en su mayoría partidaria de una tesis restringida de documento, mientras que contemporáneamente sean cada vez más los autores que abogan por una concepción amplia de dicho soporte material.

${ }^{26}$ En este sentido encontramos, por ejemplo, la sentencia del Tribunal Supremo español de 2 de diciembre de 2000, que señala: "Si bien es cierto que ese concepto de documento ha sido clarificado en el artículo 26 del vigente Código de 1995 (...), no lo es menos que durante la vigencia del anterior también se consideró que los soportes informáticos podían ser objeto de falsedad penal, y así tenemos que la sentencia de esta Sala de 24 de noviembre de 1997 (...), que se apoya a su vez en las sentencias de 3 de junio y 11 de octubre de 1994 (...), nos indica que ha de entenderse por documentos a esos efectos, no sólo el escrito plasmado en papel según el criterio tradicional, sino también todo aquello que se le pueda asimilar, por ejemplo, un disquete, un documento de ordenador, un vídeo, una película, etc., «con un criterio moderno de interacción de las nuevas realidades tecnológicas en el sentido en que la palabra documento figura en algunos diccionarios como cualquier cosa que sirve para ilustrar o comprobar algo»". 


\section{MAYER, Laura; VERA, Jaime "El documento como objeto material de las falsedades documentales y del sabotaje informático en el Derecho penal chileno".}

incluso antes de la consagración del artículo 26, fue mayoritariamente proclive a una visión amplia de dicho objeto ${ }^{27}$.

En nuestro país, la mayoría de los autores se ha inclinado por una concepción restringida de documento, confiriendo tal carácter sólo a los soportes escritos ${ }^{28}$. Así, por ejemplo, a juicio de Garrido, de lo que se trata es de encontrar una noción normativa que armonice con los textos vigentes, especialmente con las limitaciones que impone la redacción de los tipos legales, que no pueden interpretarse de manera extensiva sin incurrir en aplicaciones analógicas proscritas por el principio de legalidad ${ }^{29}$. De acuerdo con ello, el concepto de documento que debe adoptarse es el tradicional, entendiéndose por tal aquella "manifestación de voluntad o consignación de hechos (...) escrita y más o menos permanente, realizada por una persona, que puede tener consecuencias jurídicas" ${ }^{30}$.

Una visión distinta plantea Etcheberry, quien propone un concepto amplio de documento, comprensivo de todo objeto que represente un hecho o una manifestación de pensamiento, emanado de un autor y fijado en forma permanente. Para llegar a esta conclusión, dicho autor utiliza como referente normativo lo dispuesto en el artículo 113 bis del antiguo Código de Procedimiento Penal, que admitía como prueba (indicio o base de presunción) películas cinematográficas, fotografías, fonografías y otros sistemas de reproducción de la imagen y el sonido, versiones taquigráficas y, en general, cualquier medio apto para producir fe. Este precepto, según Etcheberry, era revelador de la imposibilidad de prescindir, en el establecimiento de normas reguladoras del tráfico probatorio, de las nuevas

\footnotetext{
${ }^{27}$ Así VILLACAMPA, La falsedad, cit. nota $\mathrm{n}^{\circ}$ 8, pp. 98 y s. ("La configuración externa del documento ha evolucionado de tal forma que en la actualidad ya no puede ser concebida únicamente como la expresión de un pensamiento por escrito, generalmente sobre el papel, utilizando caracteres fonéticos, puesto que el avance de la tecnología ha hecho surgir nuevos medios que permiten la fijación de declaraciones de pensamiento, como las cintas magnetofónicas y los disquetes de ordenador"). En el mismo sentido BONÉ, Juan; SOTERAS, Rafael, De las falsedades. Comentario a los artículos 386 al 403 del Código Penal de 1995, Barcelona: Bosch, 2000, pp. 173 y ss.; CALLE, María Victoria, Falsedades documentales no punibles, Madrid: Editoriales de Derecho Reunidas, 1998, p. 108; FERNÁNDEZ, Pilar, Delito de falsedad en documento público, oficial y mercantil, Madrid: Marcial Pons, 1996, p. 137; GARCÍA, Falsedades, cit. nota $\mathrm{n}^{\circ}$ 9, p. 67; MUÑOZ CONDE, Francisco, Derecho penal parte especial, 20ª edición, Valencia: Tirant lo blanch, 2015, pp. 626 y s. En contra CAMARGO, "Falsificación”, cit. nota n 22, p. 522.

${ }^{28}$ Véase HERNÁNDEZ, Héctor, "Uso indebido de tarjetas falsificadas o sustraídas y de sus claves", Revista Política Criminal, $\mathrm{n}^{\circ} 5$ (2008), pp. 1-38, p. 4 con referencias ulteriores.

${ }^{29}$ Véase GARRIDO, Mario, Derecho penal. Parte especial, tomo IV, reimpresión de la $4^{\text {a }}$ edición, Santiago: Editorial Jurídica de Chile, 2011, p. 55.

${ }^{30}$ GARRIDO, Derecho penal, cit. nota $n^{\circ} 29$, p. 57; todavía más restrictivo GARRIDO, Mario, "El documento, en especial el público o auténtico, en el ámbito penal", Revista de Derecho de la Pontificia Universidad Católica de Valparaíso, ${ }^{\circ}$ XXVI (2005), pp. 195-200, p. 199, al postular que el documento público o auténtico que puede ser falsificado ha de tener un "sostén en papel", además de encontrarse escriturado. También demandan que el documento esté escrito LABATUT, Gustavo, Derecho penal, tomo II, $7^{\text {a }}$ edición actualizada por el profesor Julio Zenteno Vargas, Santiago: Editorial Jurídica de Chile, 2000, p. 53; GUZMÁN, José Luis, "Defensas: Capítulo V. Falsedad documental y supresión de actuaciones en expedientes judiciales", en: GUZMÁN, José Luis, Estudios y defensas penales, $3^{\text {a }}$ edición aumentada, Santiago: Legal Publishing, 2009, pp. 511-523, p. 513; con matices POLITOFF, Sergio; MATUS, Jean Pierre; RAMÍREZ, María Cecilia, Lecciones de Derecho penal chileno. Parte especial, reimpresión de la $2^{\mathrm{a}}$ edición, Santiago: Editorial Jurídica de Chile, 2012, pp. 558 y s. En la doctrina argentina exigen asimismo que el documento esté escrito CREUS, Carlos, Falsificación de documentos en general, $3^{\mathrm{a}}$ edición actualizada y ampliada, Buenos Aires: Astrea, 1999, pp. 13 y ss.; CARRERAS, Los Delitos, cit. nota n 4, p. 50.
} 


\section{Polít. crim. Vol. 14, No 27 (Julio 2019), Art. 12, pp. 419-455 [http://politcrim.com/wp-content/uploads/2019/05/Vol14N27A12.pdf]}

y modernas técnicas para la fijación de pensamientos y hechos, surgidas con los avances tecnológicos del último siglo ${ }^{31}$.

A nuestro juicio, esta segunda postura es preferible, fundamentalmente en atención a dos órdenes de consideraciones. Por una parte, es indiscutible que en el moderno tráfico jurídico el soporte escrito ha dejado de ocupar el lugar de privilegio que tenía al tiempo de dictación del Código Penal — hace casi 150 años-. En esa línea, los documentos escriturados han ido perdiendo terreno frente a las nuevas formas de fijación del pensamiento humano aparecidas durante el siglo pasado y el actual, por ejemplo, las cintas magnetofónicas y, más recientemente, los soportes informáticos ${ }^{32}$. Desde este punto de vista, negar calidad documental a tales objetos puede ocasionar graves vacíos de punibilidad y dejar sin castigo a una serie de conductas que merecen sanción penal, pues con ellas se verifica una genuina afectación del bien jurídico tutelado ${ }^{33}$.

Por otra parte, la ausencia de un concepto penal de documento fijado a nivel legislativo lleva a considerar el mayor desarrollo que de este tema ha existido en otros sectores del ordenamiento jurídico - fundamentalmente civil y procesal-, que no han ignorado la necesidad de adecuar la normativa vigente a las especificidades que presenta el tráfico documental de nuestros días. En ese orden de ideas y, según veremos, no parece razonable que producto de los cambios sociales las restantes ramas del Derecho evolucionen hacia la ampliación del concepto de documento, pero que el Derecho penal conserve una interpretación restringida del mismo en atención a las condiciones que se tuvieron a la vista al momento de la dictación del Código punitivo. Adoptar una noción amplia de documento tiende, en cambio, a favorecer la sistematicidad de la norma penal en su dimensión externa,

${ }^{31}$ Véase ETCHEBERRY, Alfredo, Derecho Penal. Parte Especial, tomo IV, reimpresión de la $3^{\text {a }}$ edición, Santiago: Editorial Jurídica de Chile, 2010, pp. 154 y ss. Más recientemente también se ha inclinado por una concepción amplia de documento ROJAS, Luis Emilio, "Falsedad documental como delito de engaño", Revista Chilena de Derecho, vol. 41, n 2 (2014), pp. 523-554, p. 541, quien lo entiende como "una declaración de una persona fijada en signos que expresan en el tráfico jurídico un acto de voluntad o la observación de una circunstancia fáctica jurídicamente relevante"; véase igualmente ROJAS, Luis Emilio, Teoría funcionalista de la falsedad documental, Madrid: Marcial Pons, 2017, p. 72. En el mismo sentido, pero en la doctrina argentina, PÉREZ, Gabriel, Delitos de falsedad documental, Buenos Aires: Hammurabi, 2013, p. 59, para quien documento es "toda declaración materializada en forma perdurable que permita reconocer a un emisor, destinada a establecer relaciones jurídicas e idónea para ello".

${ }^{32}$ En este mismo sentido MARTÍNEZ-PEREDA, José Manuel, "Las falsedades en documentos oficiales", en: Las falsedades documentales. Libro homenaje a Enrique Ruiz Vadillo, Granada: Comares, 1994, pp. 77-120, p. 89, quien ya hacia fines del siglo pasado afirmaba respecto del concepto de documento: “(...) no puede reducirse por el peso de una tradición histórica al escrito en este tiempo en que tanto la Administración como los particulares disfrutan y utilizan (...) medios informáticos. Se utilizan, asimismo, la fotografía, incluso con fines identificatorios y de seguridad no sólo en los servicios policiales, sino en bancos y empresas privadas. Remitir la falsedad documental al sólo escrito es volver la espalda a la realidad actual y permanecer anclado en un pasado que va cambiando sin cesar".

${ }^{33}$ Según se analizará, dicha impunidad podría producirse respecto del documento público más utilizado, esto es, la escritura pública, pues cada día es más frecuente en el oficio notarial el uso de copias autorizadas que se extienden como documentos electrónicos, mediante la aplicación de las disposiciones de la Ley $\mathrm{N}^{\circ} 19.799$. Algo similar podría acontecer con las copias otorgadas por conservadores. Así, entonces, la falsedad de una escritura pública emitida en papel se castigaría, pero no la extendida en formato electrónico, cuestión que carece de sentido. 


\section{MAYER, Laura; VERA, Jaime "El documento como objeto material de las falsedades documentales y del sabotaje informático en el Derecho penal chileno".}

evitando contradicciones entre el concepto de documento y la protección que a él se brinda al interior del ordenamiento jurídico ${ }^{34}$.

\subsection{La ampliación del concepto de documento en el Derecho positivo chileno. El documento electrónico como objeto material del delito de falsedad}

La tendencia legislativa a ampliar la noción de documento se inició con ciertas reformas introducidas al Código de Procedimiento Penal de 1906 y empezó a consolidarse con la dictación del Código Procesal Penal del año 2000. Este último cuerpo legal dispuso un sistema de libertad probatoria, que se proyectó entre otros aspectos a los medios de prueba. Sin perjuicio de que no existe en dicho Código una norma que se refiera expresamente a la naturaleza documental de los soportes surgidos con motivo de los avances tecnológicos, sí se prevén mecanismos para la incorporación al juicio oral de los denominados "otros medios", expresión que es inclusiva de películas cinematográficas, fotografías, fonografías, videograbaciones y otros sistemas de reproducción de la imagen o del sonido, versiones taquigráficas y, en general, de cualquier medio apto para producir fe (artículo 323) ${ }^{35}$.

Además, como analizaremos luego (véase infra el punto 3.), se han presentado iniciativas legislativas orientadas a incluir expresamente a los documentos electrónicos como objeto material de las falsedades documentales, destacando el Mensaje $\mathrm{N}^{\circ} 13-348$, de 25 de septiembre de 2002 (Boletín $\mathrm{N}^{\circ} 3083-07$ ).

La tendencia legislativa a ampliar el concepto de documento se ha visto confirmada con la dictación de la Ley $\mathrm{N}^{\circ}$ 18.845, sobre Sistemas de Microcopia o Micrograbación de Documentos, publicada en el Diario Oficial el 3 de noviembre de 1989, y con la dictación de la Ley $\mathrm{N}^{\circ}$ 19.799, sobre Documentos Electrónicos, Firma Electrónica y Servicios de Certificación de dicha Firma, publicada en el Diario Oficial con fecha 12 de abril de 2002.

La Ley $\mathrm{N}^{\circ} 18.845$, en su artículo $1^{\circ}$, considera microforma a "(...) cualquier alternativa de formatos de películas fotográficas, microfilmes u otros elementos análogos que contengan imágenes de documentos originales como producto del proceso de microcopia o micrograbado y que sean susceptibles de ser reproducidos". Asimismo, dicho cuerpo legal

\footnotetext{
${ }^{34}$ Este planteamiento puede entenderse como una concreción de la denominada interpretación "progresiva" o "evolutiva", que implica adaptar el sentido del texto a las necesidades del presente. Véase COBO DEL ROSAL, Manuel; VIVES, Tomás, Derecho Penal. Parte General, $5^{\text {a }}$ edición, Valencia: Tirant lo blanch, 1999, p. 121. Véase asimismo GARCÍA-PABLOS, Antonio, Introducción al Derecho Penal: Instituciones, fundamentos y tendencias del Derecho Penal, vol. I, reimpresión de la $5^{\text {a }}$ edición, Madrid: Centro de Estudios Ramón Areces, 2014, p. 825.

${ }^{35}$ En esa línea, la instauración del nuevo proceso penal constituyó una clara muestra de la importancia que han adquirido las modernas formas de fijación documental, puesto que su carácter eminentemente oral determinó la necesidad de que surgieran nuevos mecanismos de registro de las actuaciones procesales. Así, las normas del Párrafo 6, del Título II, del Libro I del Código Procesal Penal obligan al registro de las audiencias a través de medios aptos para producir fe, que permitan garantizar la conservación y reproducción de su contenido, imponiéndose en la práctica, primero, los soportes magnetofónicos y, luego, los formatos de audio multimedia y digital. Pues bien, si se altera o destruye a través de cualquier técnica el contenido de dichos soportes, tal comportamiento ¿debiese resultar impune por carecer esos objetos del carácter de medios escritos? A nuestro entender, no obstante el uso de registros que han sido previamente alterados quedará cubierto en un buen número de casos por el tipo de presentación de pruebas falsas, otras hipótesis podrían terminar injustificadamente sin castigo si se adopta una postura restringida del concepto de documento.
} 


\section{Polít. crim. Vol. 14, No 27 (Julio 2019), Art. 12, pp. 419-455 [http://politcrim.com/wp-content/uploads/2019/05/Vol14N27A12.pdf]}

dispone que el método que se emplee para tales efectos "deberá garantizar, en una medida equiparable a la de los documentos originales, la duración, indelebilidad, integridad, legibilidad y fidelidad de las microformas que se usen y la obtención de copia fiel de los documentos microcopiados o micrograbados" (artículo $2^{\circ}$ ). En consonancia con ello, el artículo $8^{\circ}$ de la misma ley castiga como delito la falsificación de microformas, haciendo un reenvío a los delitos de falsedad de los Párrafos 4 y 5 del Libro II del Código Penal. Consiguientemente, la Ley $\mathrm{N}^{\circ} 18.845$ atribuye carácter documental a soportes no escriturados, tales como formatos de películas fotográficas o microfilmes.

Por su parte, la Ley $\mathrm{N}^{\circ} 19.799$ establece, entre otras cosas, una definición de documento electrónico que es armónica con el concepto amplio de documento indicado supra. En efecto, el artículo $2^{\circ}$, letra d) de la referida ley entiende por documento electrónico “(...) toda representación de un hecho, imagen o idea que sea creada, enviada, comunicada o recibida por medios electrónicos y almacenada de un modo idóneo para permitir su uso posterior" 36-37. Además, salvo ciertos supuestos excepcionales, la ley valida el uso de firmas electrónicas ${ }^{38}$ en el tráfico documental e incluso admite la posibilidad de utilizar fechas electrónicas ${ }^{39}$. Finalmente, la Ley $\mathrm{N}^{\circ} 19.799$ reconoce valor probatorio a los documentos electrónicos que se presenten en procesos civiles, equiparando su status al de los documentos tradicionales ${ }^{40}$.

\footnotetext{
${ }^{36}$ Como una manifestación normativa más reciente se puede mencionar el Reglamento de la Ley $\mathrm{N}^{\circ} 20.285$, sobre Acceso a la Información Pública, cuyo artículo 3 letra e) define "documentos" en los siguientes términos: "Todo escrito, correspondencia, memorándum, plano, mapa, dibujo, diagrama, documento gráfico, fotografía, microforma, grabación sonora, video, dispositivo susceptible de ser leído mediante la utilización de sistemas mecánicos, electrónicos o computacionales y, en general, todo soporte material que contenga información, cualquiera sea su forma física o características, así como las copias de aquéllos". Sobre el sentido de esta definición véase MENESES, Claudio, El documento público como medio de prueba en el proceso civil chileno, Santiago: Thomson Reuters, 2017, pp. 31 y ss.

${ }^{37}$ Para dicho concepto, desde un punto de vista doctrinal, por ejemplo, GONZÁLEZ, Juan José, "Protección penal de sistemas, elementos, datos, documentos y programas informáticos", Revista Electrónica de Ciencia Penal y Criminología, $\mathrm{n}^{\circ}$ 01-14 (1999). En relación con el concepto de documento electrónico establecido en dicha norma cabe efectuar una aclaración: que en él se plasme un "hecho, imagen o idea que sea creada, enviada, comunicada o recibida por medios electrónicos" no debe entenderse como una prescindencia, en esta clase de soportes, de una declaración del pensamiento humano, proveniente de su autor. Consiguientemente, no integran el "documento electrónico" aquellas declaraciones que, no obstante constar en el soporte, tienen un origen puramente maquinal, o sea, que son el resultado del uso del medio electrónico de reproducción o almacenamiento. Distinto es el supuesto de las "declaraciones" que, a pesar de tener un origen maquinal, luego son asumidas como declaraciones del pensamiento propias, por parte del autor del documento, pues en tal evento se trata efectivamente de declaraciones humanas, que son el resultado de una acción documentadora, y no de un puro proceso artificial y autónomo.

${ }^{38} \mathrm{La}$ firma electrónica, además, se concibe de una manera muy amplia en el artículo $2^{\circ}$ letra g), como: "cualquier sonido, símbolo o proceso electrónico, que permite al receptor de un documento electrónico identificar al menos formalmente a su autor".

${ }^{39} \mathrm{La}$ admisión de la fecha electrónica obedece a una modificación introducida por la Ley $\mathrm{N}^{\circ} 20.217$, que incluyó en el artículo $2^{\circ}$ una letra i), según la cual, ella es definida de manera amplísima como un "conjunto de datos en forma electrónica utilizados como medio para constatar el momento en que se ha efectuado una actuación sobre otros datos electrónicos a los que están asociados".

${ }^{40}$ En ese sentido, el artículo $5^{\circ}$ señala: "Los documentos electrónicos podrán presentarse en juicio y, en el evento de que se hagan valer como medio de prueba, habrán de seguirse las reglas siguientes:

1. Los señalados en el artículo anterior, harán plena prueba de acuerdo con las reglas generales, y

2. Los que posean la calidad de instrumento privado, en cuanto hayan sido suscritos con firma electrónica avanzada, tendrán el mismo valor probatorio señalado en el número anterior. Sin embargo, no harán fe
} 


\section{MAYER, Laura; VERA, Jaime "El documento como objeto material de las falsedades documentales y del sabotaje informático en el Derecho penal chileno".}

Como consecuencia de la promulgación de la Ley $\mathrm{N}^{\circ} 19.799$, el entonces Ministerio de Economía, Fomento y Reconstrucción emitió el Decreto Supremo $N^{\circ} 181$, que aprueba el Reglamento de dicha ley. Con la dictación de esa normativa y de otras modificaciones posteriores, el documento electrónico y la firma electrónica se han ido asentando como sistemas para fijar e identificar determinadas informaciones al interior del tráfico.

Adicionalmente, en virtud de la publicación de la Ley N 19.799, la Corte Suprema emitió un Auto Acordado el 10 de noviembre de 2006 "sobre uso de documento y firma electrónica por notarios, conservadores y archiveros judiciales", con el que se consolidó la ampliación del concepto de documento descrita supra. En efecto, dicha normativa permite el uso de documentos electrónicos respecto de algunas de las más relevantes actuaciones en el tráfico jurídico documental. Tal es el caso de documentos extendidos por notarios, por ejemplo, escrituras públicas; de documentos emitidos por conservadores de bienes raíces, como copias de inscripción y certificados de hipotecas y gravámenes; y, en general, de todos los documentos que es posible obtener en los registros de archiveros judiciales.

Dicha ampliación del concepto de documento ha llevado a introducir nuevos términos en materia documental, como son los de documento electrónico y de firma electrónica, referidos anteriormente.

Para efectos analíticos, en este desarrollo también es posible plantear la noción de "documento informático", que puede ser entendida como una especie dentro del género "documento electrónico", sobre todo si se considera la extensión con que este último aparece definido en la Ley $\mathrm{N}^{\circ}$ 19.799. Concretamente, con el término documento informático puede comprenderse toda representación de un hecho, imagen o idea que sea creada, enviada, comunicada o recibida por medios informáticos y almacenada de un modo idóneo para permitir su uso posterior. A su turno, los medios informáticos se refieren a todos aquellos mecanismos que involucran el tratamiento automatizado de la información a través de computadoras. En este contexto aparece también el concepto de "dato informático", que viene a desempeñar en el ámbito de la informática —incluso con consagración positiva ${ }^{41}$ - el papel que cumple la idea de declaración del pensamiento humano o, simplemente, de información, en la documentación tradicional.

Cabe hacer presente que la Ley $\mathrm{N}^{\circ} 19.799$ consagró tres ideas de relevancia respecto del vínculo existente entre los documentos consignados en papel y los documentos electrónicos.

respecto de su fecha, a menos que esta conste a través de un fechado electrónico otorgado por un prestador acreditado.

En el caso de documentos electrónicos que posean la calidad de instrumento privado y estén suscritos mediante firma electrónica, tendrán el valor probatorio que corresponda, de acuerdo a las reglas generales".

${ }^{41}$ En efecto, el Convenio sobre Ciberdelincuencia del Consejo de Europa, de 2001, del que el Estado chileno recientemente pasó a ser parte, contempla normas relativas a dicho concepto en relación con la criminalidad informática. Así, el artículo $1^{\circ}$ letra b. indica que se entenderá por "datos informáticos" para los efectos del Convenio "toda representación de hechos, información o conceptos expresados de cualquier forma que se preste a tratamiento informático, incluidos los programas diseñados para que un sistema informático ejecute una función". 


\section{Polít. crim. Vol. 14, № 27 (Julio 2019), Art. 12, pp. 419-455 [http://politcrim.com/wp-content/uploads/2019/05/Vol14N27A12.pdf]}

Por una parte, el artículo $1^{\circ}$ inciso segundo de dicha normativa contempla diversos principios aplicables a esta materia, entre los que destaca el de "equivalencia del soporte electrónico al soporte de papel". Según este principio no es posible afirmar más la supremacía del papel respecto de otros soportes, como el electrónico.

Por otra parte, el artículo $3^{\circ}$ inciso primero de la referida ley establece: "Los actos y contratos otorgados o celebrados por personas naturales o jurídicas, suscritos por medio de firma electrónica, serán válidos de la misma manera y producirán los mismos efectos que los celebrados por escrito y en soporte de papel. Dichos actos y contratos se reputarán como escritos, en los casos en que la ley exija que los mismos consten de ese modo, y en todos aquellos casos en que la ley prevea consecuencias jurídicas cuando constan igualmente por escrito". En virtud de lo señalado en esta disposición y de lo prescrito en el ordenamiento jurídico civil, procesal civil y procesal penal, es posible sostener que puede haber documentos electrónicos públicos y documentos electrónicos privados, debiendo castigarse su falsedad, como veremos luego, de acuerdo con los respectivos tipos penales, establecidos en los artículos 193 y ss. del Código Penal chileno, lo que tiene incidencia en relación con la penalidad aplicable a cada uno de ellos.

Finalmente, la Ley $\mathrm{N}^{\circ} 19.799$ atribuye una gran importancia al uso de la firma electrónica en los documentos de dicha naturaleza, sobre todo cuando se trata de una firma electrónica avanzada $^{42}$. Así, según el artículo $4^{\circ}$ de la referida ley, los documentos electrónicos que tengan la naturaleza de documentos públicos deben ser suscritos mediante firma electrónica avanzada que, en los términos de la ley, ofrecería una mayor seguridad en el tráfico jurídico respecto de la recognoscibilidad del autor del documento. Esta idea se ve reforzada en las disposiciones del Título II de la Ley $\mathrm{N}^{\circ} 19.799$, en lo que respecta a la documentación electrónica proveniente de órganos estatales. Pues, junto con permitirse el uso de esa clase de firma en los documentos que de ellos emanan (artículo $6^{\circ}$ ), se reitera que para que tengan la naturaleza de documentos públicos deben suscribirse con firma electrónica avanzada (artículo $7^{\circ}$ ).

Más allá de la distinción entre diversas clases de documento, lo relevante en la actualidad es que la declaración del pensamiento humano de que se trate quede fijada en un soporte de forma indeleble. Y ello puede ocurrir, sea que la fijación se produzca en soportes electrostáticos, magnéticos, ópticos, de estado sólido o de cualquier otra índole.

A nuestro juicio, los documentos electrónicos pueden ser objeto material de una serie de delitos, entre ellos, de las figuras de falsedad y del sabotaje informático. No obstante, es respecto de las primeras que se han planteado objeciones en torno a la supuesta incompatibilidad entre la tipificación de las falsedades y la adopción de un concepto amplio de documento, como el planteado supra. Según veremos, tales objeciones carecen de un sustento positivo o doctrinal concluyente y pueden ser superadas sin mayores dificultades.

\footnotetext{
${ }^{42}$ La que se define en el artículo $2^{\circ}$ letra g), como "aquella certificada por un prestador acreditado, que ha sido creada usando medios que el titular mantiene bajo su exclusivo control, de manera que se vincule únicamente al mismo y a los datos a los que se refiere, permitiendo la detección posterior de cualquier modificación".
} 


\section{MAYER, Laura; VERA, Jaime "El documento como objeto material de las falsedades documentales y del sabotaje informático en el Derecho penal chileno".}

De un lado, no es efectivo que las modalidades típicas previstas en el artículo 193 del Código Penal requieran que el sujeto activo opere siempre sobre un papel escrito ${ }^{43}$. Así, tratándose de la contrafacción de letra, firma o rúbrica del número 1 y de la alteración de fechas verdaderas del número 5 , resulta perfectamente factible su configuración a través de manipulaciones informáticas que, por ejemplo, supongan la modificación de una firma electrónica, o bien, una alteración de la fecha de suscripción del documento. En ese mismo sentido, no se visualiza inconveniente alguno para la aplicación de las modalidades de falsedad ideológica de los números 2, 3, 4 y 7, así como de las falsedades impropias de ocultación del número 8 y de uso del artículo 196 a soportes materiales no fijados en un texto escrito, como ocurre con los objetos mencionados precedentemente. Incluso, tratándose de las falsedades materiales, el número 6 del artículo 193 del Código Penal establece una modalidad comisiva bastante amplia, consistente en hacer en documento verdadero cualquiera alteración o intercalación que varíe su sentido. Pues bien, conforme con una interpretación que no exceda el sentido literal posible de la descripción típica, dicha modalidad resulta plenamente aplicable a cualquier objeto, no necesariamente escrito, v. gr. soportes electrostáticos, magnéticos, ópticos o de estado sólido ${ }^{44}$.

De otro lado, tampoco parece correcto negar carácter documental a los soportes no escriturados, argumentando que a su respecto sería más fácil la manipulación, a la vez que más difícil la prueba de su falsedad. En este sentido, como expone Queralt, si bien los soportes distintos del papel en ocasiones pueden ser poco fiables y susceptibles de manipulación, no existe un soporte inexpugnable; más aún, la pretendida fiabilidad del papel ha tendido a desaparecer, siendo en nuestros días todos los documentos igualmente vulnerables ${ }^{45}$. Asimismo, de acuerdo con Villacampa, es posible que los documentos no escritos, como es el caso de las cintas magnetofónicas, sean materia de un cotejo en términos análogos a los documentos escriturados; mientras que la recognosibilidad del autor puede llegar a ser mucho más sencilla, por ejemplo, en las grabaciones de video o en las cintas de audio que en los documentos escritos ${ }^{46}$.

Lo dicho no impide reconocer que existen documentos en los que la forma escrita en papel resulta esencial en tanto requisito ad substantiam, como la escritura pública de compraventa de un bien raíz (artículo 1801 del Código Civil), que en caso de no concurrir

\footnotetext{
${ }^{43}$ En cambio, exige que el objeto material de los comportamientos del artículo 193 del Código Penal sea un papel escrito GARRIDO, "El documento", cit. nota n 30, p. 199.

${ }^{44}$ Nos llama la atención que la mayor amplitud del concepto legal de documento que se observa en la evolución expuesta no haya sido considerada por la jurisprudencia de nuestros tribunales. En efecto, hay sentencias recientes que siguen exigiendo que el documento esté contenido en papel, v. gr. el fallo de la Corte de Apelaciones de Temuco, de fecha 9 de enero de 2012, causa rol $\mathrm{N}^{\circ} 1100-2011$. Se trata de la resolución de una querella de capítulos en la que el Ministerio Público imputó a un juez de garantía el hecho de haber simulado en el registro de audio de una audiencia la presencia de un fiscal, instruyendo a un funcionario administrativo que así lo consignara también en el acta. En definitiva, la sentencia desestimó dicho capítulo por estimar que el registro de audio de una audiencia no constituye un documento contenido papel; y en cuanto a su calificación como documento electrónico, al no haber sido suscrito por un funcionario, ni menos contar con la firma electrónica avanzada, la alteración de su contenido no podía dar origen a la figura penal del articulo $193 \mathrm{~N}^{\circ} 2$ del Código Penal (considerando décimo primero).

${ }^{45}$ QUERALT, "La falsedad", cit. nota ${ }^{\circ} 14$, p. 1128.

${ }^{46}$ VILLACAMPA, La falsedad, cit. nota ${ }^{\circ}$ 8, p. 113.
} 


\section{Polít. crim. Vol. 14, № 27 (Julio 2019), Art. 12, pp. 419-455 \\ [http://politcrim.com/wp-content/uploads/2019/05/Vol14N27A12.pdf]}

se traduce en la ineficacia jurídica del acto ${ }^{47}$. Pero tal ineficacia sólo se proyecta al ámbito civil, y no obsta a la configuración de una falsedad documental penalmente relevante. Esta misma idea es recogida en el artículo $3^{\circ}$ inciso segundo de la Ley $\mathrm{N}^{\circ} 19.799$ que, como se señaló, tras indicar que los actos y contratos suscritos mediante firma electrónica serán tan válidos como los celebrados por escrito y en papel, dispone que ello no será aplicable a los actos y contratos en que la ley exige una solemnidad que no sea susceptible de cumplirse mediante documento electrónico, en que la ley requiera la concurrencia personal de alguna de las partes, o que se refieran al Derecho de familia.

\section{El documento electrónico como objeto material del delito de sabotaje informático en el Derecho penal chileno}

A diferencia de lo que ocurre en materia de falsedades documentales, que pueden recaer sobre documentos escriturados (en papel) y electrónicos, las hipótesis de sabotaje informático que regula la Ley $\mathrm{N}^{\circ} 19.223$ sólo pueden referirse a documentos electrónicos. De esta forma, el delito de sabotaje informático considera modalidades de ataque que tienen en cuenta la desmaterialización del objeto material sobre el que se orienta la conducta típica, pues ésta se dirige fundamentalmente contra el software o soporte lógico de un sistema informático ${ }^{48}$. En específico, en un documento electrónico se distinguen dos aspectos: por una parte, el soporte tangible, que puede estar constituido por el disco que lo contiene u objetos tales como un diskette, un CD Rom o un disco duro externo; y la declaración del pensamiento humano que se expresa a través de impulsos, ondas o instrucciones electrónicas configuradoras de un programa ${ }^{49}$.

La Ley $\mathrm{N}^{\circ} 19.223$ consagra dos tipos penales que resultan de interés en relación con el análisis que aquí se efectúa. En primer lugar, está la figura del artículo $1^{\circ}$, que castiga “[a]1 que maliciosamente destruya o inutilice un sistema de tratamiento de información o sus partes o componentes, o impida, obstaculice o modifique su funcionamiento"; hipótesis que recibe una pena agravada "[s]i como consecuencia de estas conductas se afectaren los datos contenidos en el sistema". En segundo lugar, está el tipo del artículo $3^{\circ}$, que sanciona "[a]l que maliciosamente altere, dañe o destruya los datos contenidos en un sistema de tratamiento de información".

La doctrina chilena entiende que el delito del artículo $1^{\circ}$ de la Ley $\mathrm{N}^{\circ} 19.223$ puede recaer indistintamente sobre el soporte físico (hardware), o bien, sobre el soporte lógico (software) de un sistema de tratamiento automatizado de la información ${ }^{50}$. Esta opción

\footnotetext{
${ }^{47}$ En esa línea FERNÁNDEZ, Delito, cit. nota ${ }^{\circ}$ 27, p. 137.

48 Véase JIJENA, Renato, "Delitos informáticos, Internet y Derecho", en: RODRÍGUEZ, Luis (coord.), Delito, pena y proceso. Libro homenaje a la memoria del profesor Tito Solari Peralta, Santiago: Editorial Jurídica de Chile, 2008, pp. 145-162, p. 149.

${ }^{49}$ En un sentido similar MATA Y MARTÍN, Ricardo, “Capítulo IV. Perspectivas sobre la protección penal del software", en: ROMEO, Carlos (coord.), El cibercrimen: nuevos retos jurídico-penales, nuevas respuestas político-criminales, Granada: Comares, 2006, pp. 97-152, p. 104.

50 Véase LONDOÑO, Fernando, "Los Delitos Informáticos en el Proyecto de Reforma en Actual Trámite Parlamentario", Revista Chilena de Derecho Informático, n 4 (2004), pp. 171-190, pp. 185 y s.
} 


\section{MAYER, Laura; VERA, Jaime "El documento como objeto material de las falsedades documentales y del sabotaje informático en el Derecho penal chileno".}

político - criminal que habría consagrado el legislador nacional es criticada ${ }^{51}$, entre otras cosas, por estimarse que las conductas referidas al hardware, del artículo $1^{\circ}$, más bien se relacionan con los tipos clásicos de daños que con la delincuencia informática propiamente $\mathrm{tal}^{52}$.

Más allá de la valoración negativa que se efectúa de la Ley $\mathrm{N}^{\circ} 19.223$ en general, y de los tipos de sabotaje informático en particular, consideramos necesario plantear una interpretación que parta de la vinculación sistemática entre los delitos de los artículos $1^{\circ}$ (inciso primero y segundo) y $3^{\circ}$ de la ley referida, pero también de la relación entre dichas figuras y las hipótesis de daños contempladas en el Párrafo 10 del Título IX del Libro II del Código Penal.

A nuestro juicio, las conductas que sólo involucran destrucción o inutilización de un hardware deben castigarse mediante los tipos de daños del Código Penal ${ }^{53}$. Ello ocurriría, por ejemplo, si se destruye o inutiliza el teclado, el mouse, la torre o pantalla de un computador mediante golpes con un objeto contundente.

Por su parte, los comportamientos que implican destrucción o inutilización de un hardware que contiene datos, pero que no resultan destruidos o inutilizados, han de castigarse en virtud del artículo $1^{\circ}$ inciso primero de la Ley $\mathrm{N}^{\circ}$ 19.223. Tal sería el caso de quien, también por medio de un objeto contundente, destruye o inutiliza el disco duro de un computador, excluyendo sus datos. En un ejemplo como el señalado se aplica el delito informático y no el de daños por el peligro (concreto) a que se exponen los datos contenidos en el hardware.

En cambio, las conductas que suponen destrucción o inutilización de un hardware que contiene datos que sí resultan destruidos o inutilizados han de sancionarse de acuerdo con el artículo $1^{\circ}$ inciso segundo de la referida ley. Tal sería el caso de quien, nuevamente por medio de un objeto contundente, destruye o inutiliza el disco duro de un computador,

\footnotetext{
${ }^{51}$ Así JIJENA, "Delitos", cit. nota ${ }^{\circ}$ 48, pp. 150 y ss., quien atribuye este proceder a la ignorancia del legislador que dictó dicha normativa.

${ }^{52}$ En esa línea HERNÁNDEZ, Héctor, "Tratamiento de la criminalidad informática en el derecho penal chileno. Diagnóstico y propuestas", Informe solicitado por la División Jurídica del Ministerio de Justicia (inédito), 2001, pp. $1-26$, pp. 8 y ss. Desde un punto de vista más general, con referencia a la legislación española, por ejemplo, ya GÓMEZ, Miguel, "Los Delitos Informáticos en el Derecho Español”, Informática y Derecho: Revista Iberoamericana de Derecho Informático, ${ }^{\circ} 4$ (1994), pp. 481-496, p. 486.

${ }^{53}$ Por una parte, la referencia al sistema de tratamiento de información, o sus partes o componentes, es amplia y apunta tanto al soporte físico como al soporte lógico del sistema informático de que se trate. En ese orden de ideas, cuando se alude a "partes" o "componentes" se están considerando ambos aspectos y no sólo el hardware del sistema de tratamiento automatizado de la información. Por otra parte, entender que en el artículo $1^{\circ}$ inciso primero únicamente se está haciendo referencia al hardware, fuera de desconocer que estamos frente a una ley que tipifica figuras penales relativas a la informática, introduciría una incoherencia valorativa y penológica insalvable en el sistema de delitos que suponen la destrucción patrimonial de cosas corporales muebles. Así, carecería de sentido que una normativa sobre delitos informáticos contemplara una hipótesis especial de daños respecto del hardware, sancionada además con una pena de presidio menor en su grado medio a máximo, o sea, un castigo considerablemente más alto que el establecido para el tipo penal de daños. Sobre la necesidad de coherencia en la creación de tipos penales véase, desde un punto de vista más general, OSSANDÓN, Magdalena, La formulación de tipos penales: Valoración crítica de los Instrumentos de Técnica Legislativa, Santiago: Editorial Jurídica de Chile, 2009, pp. 324 y s.
} 


\section{Polít. crim. Vol. 14, No 27 (Julio 2019), Art. 12, pp. 419-455 [http://politcrim.com/wp-content/uploads/2019/05/Vol14N27A12.pdf]}

incluyendo sus datos. Dicha hipótesis encuadra en lo que doctrinalmente se denomina sabotaje informático, comportamiento que alude, precisamente, a la destrucción o inutilización de datos contenidos en un sistema de tratamiento automatizado de la información ${ }^{54}$.

Finalmente, las conductas que únicamente importan destrucción o inutilización de datos deben sancionarse a través del artículo $3^{\circ}$ de la Ley $\mathrm{N}^{\circ}$ 19.223. Ello acontecería, por ejemplo, si se destruyen o inutilizan documentos electrónicos empleando un virus computacional. Tal hipótesis también encuadra dentro del llamado sabotaje informático, pues involucra la destrucción o inutilización de datos contenidos en un sistema de tratamiento automatizado de la información.

La interpretación que aquí se sugiere, además de partir de la vinculación sistemática entre las figuras de sabotaje informático, así como entre éstas y las hipótesis de daños, tiene en cuenta las diferencias penológicas que ellas conllevan, las que a su vez se explican por la distinta ofensividad que las caracteriza.

Así, el primer supuesto sólo significa una lesión patrimonial en un sentido tradicional, excluyéndose una afectación para los intereses tutelados específicamente en la criminalidad informática $^{55}$. De esta forma, la sanción aplicable dependerá fundamentalmente ${ }^{56}$ de la cuantía del hardware dañado y será reclusión menor en su grado mínimo o multa de 11 a 20 UTM si su valor excede de 1 UTM (daños simples, artículo 487 del Código Penal); o bien, multa de 1 UTM si su valor no excede de 1 UTM (daños-falta, artículo 495 número 21 del Código Penal).

El segundo caso implica una lesión patrimonial en un sentido tradicional, por la destrucción o inutilización de un hardware. Además, existe en él un peligro (concreto) para los intereses relacionados con los datos, que pueden identificarse con la funcionalidad informática, esto es, aquel conjunto de condiciones que posibilitan que los sistemas informáticos realicen adecuadamente las operaciones de almacenamiento, tratamiento y transferencia de datos, dentro de un marco tolerable de riesgo ${ }^{57}$; o bien, con bienes jurídicos

${ }^{54}$ Véase MIRÓ, Fernando, El cibercrimen: Fenomenología y criminología de la delincuencia en el ciberespacio, Madrid: Marcial Pons, 2012, p. 57 n. 17 con referencias ulteriores; ROMEO, Carlos, "De los delitos informáticos al cibercrimen. Una aproximación conceptual y político-criminal”, en: ROMEO, Carlos (coord.), El cibercrimen: nuevos retos jurídico-penales, nuevas respuestas político-criminales, Granada: Comares, 2006, pp. 1-42, p. 7. Con referencia a la afectación de los datos o del propio sistema informático, por ejemplo, MORÓN, Esther, "Delitos contra la confidencialidad, integridad y disponibilidad de datos y sistemas informáticos", en: Cuadernos Penales José María Lidón, $n^{\circ}$ 4, Bilbao: Universidad de Deusto, 2007, pp. 85-128, pp. 108 y s.

${ }_{55}$ Respecto de la protección de tales intereses véase MAYER LUX, Laura, "El bien jurídico protegido en los delitos informáticos", Revista Chilena de Derecho, vol. 44, n 1 (2017), pp. 235-260, pp. 248.

${ }^{56}$ Aunque poco probable, no se puede descartar la concurrencia de alguna de las circunstancias descritas en el artículo 485 del Código Penal, que dan origen a una hipótesis de daños calificados. Así, por ejemplo, el hecho podría tener lugar "en cuadrilla", de acuerdo con el numeral 4 de dicho precepto; o podría arruinar al perjudicado, según el numeral 8 de la referida disposición.

${ }^{57}$ Véase, en datelle, MAYER LUX, "El bien jurídico", cit. nota n 55 , p. 255. En este punto nos alejamos del Convenio sobre Ciberdelincuencia del Consejo de Europa, de 2001, según el cual, los delitos que analizamos tutelarían la confidencialidad, la integridad y la disponibilidad de los datos y sistemas informáticos. La razón de ello radica fundamentalmente en que estimamos que dicho bien jurídico sería una mera reformulación de 


\section{MAYER, Laura; VERA, Jaime "El documento como objeto material de las falsedades documentales y del sabotaje informático en el Derecho penal chileno".}

(más) tradicionales — - v. gr. la propiedad-, dependiendo del carácter de los datos. Consiguientemente, se trata de una figura pluriofensiva. Precisamente, la pluriofensividad del tipo del artículo $1^{\circ}$ inciso primero de la Ley $\mathrm{N}^{\circ} 19.223$ y la forma de afectar los bienes jurídicos que a él subyacen explica que se prevea una pena considerable $-\mathrm{y}$ bastante mayor que la de los daños simples-, de presidio menor en su grado medio a máximo.

La tercera hipótesis importa una lesión patrimonial en un sentido tradicional, por la destrucción o inutilización de un hardware. Asimismo, existe en ella una lesión para los intereses vinculados con los datos, que pueden identificarse con la funcionalidad informática, en el sentido antes expuesto; o bien, con bienes jurídicos (más) tradicionales — v. gr. la propiedad—, según la naturaleza de los datos. Por ende, se trata de una figura pluriofensiva. Justamente, la pluriofensividad del tipo del artículo $1^{\circ}$ inciso segundo de la Ley $\mathrm{N}^{\circ} 19.223$ y la forma de afectar los bienes jurídicos que a él subyacen explica que se prevea una pena todavía mayor a la del caso anterior, de presidio menor en su grado máximo.

Por último, el cuarto supuesto involucra una lesión para los intereses relacionados con los datos, que pueden identificarse con la funcionalidad informática, en los términos ya referidos; o bien, con bienes jurídicos (más) tradicionales — v. gr. la propiedad-, dependiendo del carácter de los datos. Por ende, se trata de una figura pluriofensiva. No obstante, como en este caso no se verifica la destrucción o inutilización de un hardware, en el artículo $3^{\circ}$ de la Ley $\mathrm{N}^{\circ} 19.223$ se prevé una pena inferior a la del artículo $1^{\circ}$, de presidio menor en su grado medio.

Cabe hacer presente que los marcos penales establecidos por el legislador en los artículos $1^{\circ}$ y $3^{\circ}$ de la Ley $\mathrm{N}^{\circ} 19.223$ no consideran todas las posibles combinaciones de intereses afectados. Así, por ejemplo, puede ocurrir que se destruya o inutilice un hardware y un software de escaso valor económico - supuesto en que se aplicaría el tipo del artículo $1^{\circ}$ inciso segundo, o sea, la figura con mayor pena- o que se altere, dañe o destruya un software de alto valor económico — en cuyo caso se aplicaría el tipo del artículo $3^{\circ}$, esto es, la figura con menor pena-. Pues bien, a fin de superar en parte la incoherencia penológica que podría seguirse de la punición de los referidos supuestos, el juez debe imponer una mayor o menor pena dentro del marco penal asignado (con consideración a lo dispuesto por el artículo 69 del Código Penal) y sancionar más o menos drásticamente las afectaciones más o menos intensas o relevantes de los bienes jurídicos tutelados.

Desde el punto de vista de los comportamientos incriminados, el tipo del artículo $1^{\circ}$ de la Ley $\mathrm{N}^{\circ} 19.223$ castiga a quien destruya o inutilice un sistema de tratamiento de información o sus partes o componentes, o bien, que impida, obstaculice o modifique su funcionamiento, agravando la pena si es que a consecuencias de tales conductas se afectan los datos contenidos en el sistema. En cambio, el tipo del artículo $3^{\circ}$ de la referida ley sanciona a quien altere, dañe o destruya los datos contenidos en un sistema de tratamiento de información.

bienes jurídicos tradicionales y que afirmar una protección copulativa de la confidencialidad, la integridad y la disponibilidad de los datos y sistemas informáticos resultaría forzado respecto de ciertos delitos informáticos. Véase cit. pp. 245 y s. 


\section{Polít. crim. Vol. 14, No 27 (Julio 2019), Art. 12, pp. 419-455 [http://politcrim.com/wp-content/uploads/2019/05/Vol14N27A12.pdf]}

A nuestro juicio, las mayores dificultades interpretativas que generan dichas hipótesis se producen a propósito de la -en principio-diversa incidencia que tiene la conducta sobre su objeto material, incluido dentro de éste el documento electrónico.

En una primera aproximación a dicha problemática podría entenderse que las conductas consistentes en destruir o inutilizar un sistema informático o destruir datos son las más graves; que los comportamientos que implican impedir el funcionamiento del sistema de tratamiento automatizado de la información o dañar datos suponen una gravedad menor; mientras que las conductas consistentes en obstaculizar o modificar el funcionamiento del sistema, o bien, alterar sus datos son las menos graves.

Teniendo en cuenta que todos los comportamientos del artículo $1^{\circ}$ inciso primero de la Ley $\mathrm{N}^{\circ} 19.223$ tienen asignada la pena de presidio menor en su grado medio a máximo y que todas las conductas del artículo $3^{\circ}$ contemplan la pena de presidio menor en su grado medio, resulta necesario interpretar cada una de esas hipótesis en relación con los restantes comportamientos regulados en dichos preceptos. Por lo tanto, ha de tratarse de un impedimento, una obstaculización, una modificación, una alteración o un daño de cierta entidad que, en todo caso, sea valorativamente equiparable a supuestos en que exista destrucción o inutilización.

Respecto del documento electrónico, si hacemos un análisis comparativo con los planteamientos que se efectúan a propósito de las falsedades documentales ${ }^{58}$, cabe afirmar que los casos de impedimento, obstaculización, modificación, alteración o daño que sanciona el delito de sabotaje informático han de tener una cierta relevancia ${ }^{59}$, esto es, referirse a los extremos principales del funcionamiento del sistema informático, apuntar a los aspectos centrales de la declaración del pensamiento humano que expresa el documento electrónico, entre otros ${ }^{60}$.

\footnotetext{
${ }^{58}$ En esa línea, por ejemplo, MATUS, Jean Pierre; RAMÍREZ, María Cecilia, Lecciones de Derecho Penal Chileno, Parte Especial, $3^{\text {a }}$ edición, tomo II, Santiago: Thomson Reuters, 2015, pp. 402, quienes exigen que se altere sustancialmente el contenido del documento, excluyendo una serie de casos en que ello no ocurriría, tales como rallarlo; introducir garabatos sin significación jurídica; efectuar alteraciones tipográficas, v. gr. introducir signos de puntuación o de otra naturaleza, que no influyan en el sentido jurídico del documento.

${ }^{59}$ Idea que, por ejemplo, en la legislación alemana se expresa a través de la exigencia de que en el sabotaje informático exista una obstaculización del tratamiento de datos considerable y de gran importancia para otra persona. Véase GERCKE, Marco; BRUNST, Phillip, Praxishandbuch Internetstrafrecht, Stuttgart: Kohlhammer, 2009, pp. 82 y s.

${ }^{60}$ Esta cuestión se vincula con otra más general, a saber, la de la relevancia jurídico penal de la destrucción o inutilización de datos de sistemas informáticos, relevancia que normalmente se identifica con la gravedad de dicho comportamiento en atención a la naturaleza de los datos (v. gr. militares, científicos, artísticos o meramente triviales); su volumen (gran o escasa cantidad de datos); las posibilidades de recuperarlos (por ejemplo, porque se encuentran respaldados); etc. Dicha exigencia típica no sólo se plantea en el Convenio sobre Ciberdelincuencia del Consejo de Europa, de 2001 (véase Declaraciones al Convenio, así como sus artículos $4^{\circ}$ y $5^{\circ}$ ), sino que también es postulada a nivel doctrinal, para limitar la tipicidad de un comportamiento que, a diferencia de los daños comunes, no se encuentra asociado a la cuantía del objeto dañado. Véase CORCOY, Mirentxu, "Problemática de la persecución penal de los denominados delitos informáticos: particular referencia a la participación criminal y al ámbito espacio temporal de comisión de los hechos", Eguzkilore, n ${ }^{\circ} 21$ (2007), pp. 7-32, p. 19. En cambio, plantea que la existencia de un sistema de back—up no altera los daños a los datos, "pues la restauración requiere un esfuerzo que ya implica reparar el
} 


\section{MAYER, Laura; VERA, Jaime "El documento como objeto material de las falsedades documentales y del sabotaje informático en el Derecho penal chileno".}

Así, por ejemplo, en caso que se impida u obstaculice el funcionamiento del sistema de tratamiento automatizado de la información, el impedimento o la obstaculización deben ser intensos o duraderos, pues sólo de esa forma ellos podrían asimilarse a la gravedad de la destrucción o inutilización del sistema ${ }^{61}$. Por su parte, la modificación o alteración siempre debe repercutir de un modo significativo en las ideas que constan en el documento electrónico. En consecuencia, si se producen impedimentos, obstaculizaciones, modificaciones o alteraciones que no son capaces de cumplir las exigencias indicadas, debe excluirse el castigo punitivo por ausencia de antijuridicidad (material) del comportamiento. Igualmente, tratándose de la hipótesis de daños, constituyen situaciones valorativas del todo diferentes aquellas que implican la afectación definitiva del documento electrónico mismo o de la declaración en él contenida (v. gr. el archivo existe pero es imposible acceder a él o al abrirlo aparecen símbolos sin significado), que aquellas que suponen la pérdida sólo temporal o recuperable de un documento electrónico. Y ello debe ser considerado por el juez a la hora de castigar (o no) el comportamiento en cuestión.

Si hacemos un análisis comparativo entre la regulación positiva de las falsedades documentales y del sabotaje informático, podemos advertir diferencias en relación con el objeto material. En efecto, las falsedades que recaen sobre un documento electrónico pueden serlo de documento electrónico público o privado, teniendo una pena muy distinta en uno y otro caso; mientras que la Ley $\mathrm{N}^{\circ} 19.223$ no diferencia entre documentos electrónicos públicos o privados para efectos de la penalidad aplicable ${ }^{62}$. Si bien no es esperable que una ley relativa a la criminalidad informática efectúe una distinción como la planteada, en este ámbito sí es posible diferenciar entre diversas clases de información y, de esta forma, arribar a algunas de las conclusiones a las que se llega en materia de falsificación de documentos. Así, el sabotaje informático de una base de datos de un organismo público, como el Registro Civil, podría tener un desvalor considerablemente mayor que el mismo comportamiento cuando se trata de la base de datos de una persona natural. Con todo, la falta de diferenciación referida en la Ley $\mathrm{N}^{\circ} 19.223$ acarrea que el juez sólo pueda ponderar este factor en el limitado espacio que le ofrece lo dispuesto por el artículo 69 del Código Penal, incluyéndolo en la cláusula de la mayor o menor extensión del mal causado por el delito.

daño causado", RIQUERT, Marcelo, Delincuencia informática en Argentina y el Mercosur, Buenos Aires: Ediar, 2009, p. 164

${ }^{61}$ Los impedimentos u obstaculizaciones graves del funcionamiento de un sistema informático corresponden a lo que se conoce como "daños funcionales", v. gr. ataques de denegación de servicios, que si bien no implican un auténtico daño a los datos, afectan de forma relevante la operatividad del sistema. Véase SALVADORI, Ivan, "La regulación de los daños informáticos en el código penal italiano", Revista de Internet, Derecho y Política, n $^{\circ} 16$ (2013), pp. $44-60$, pp. 48 y s.

${ }^{62}$ Más aún, si se siguiera la tesis, según la cual, el perjuicio en la falsificación de instrumentos privados constituye una condición objetiva de punibilidad (en ese sentido ORTIZ, Pedro, "La falsificación de instrumento privado", Revista de Ciencias Penales, tomo VII [1944], pp. 207-214, p. 209), la naturaleza del objeto falseado también incidiría en la punibilidad del hecho, descartándose el castigo cuando se trate de una falsificación de documento electrónico privado que no irroga perjuicio. 


\section{Polít. crim. Vol. 14, No 27 (Julio 2019), Art. 12, pp. 419-455 [http://politcrim.com/wp-content/uploads/2019/05/Vol14N27A12.pdf]}

\section{Problemas de delimitación entre la falsedad que recae sobre documentos electrónicos y el sabotaje informático en el Derecho penal chileno}

La existencia de puntos de contacto entre la falsificación de documentos electrónicos y el sabotaje informático resultan indesmentibles.

En primer lugar, tal vinculación se advierte ya en la regulación de los comportamientos sancionados, por cuanto varias de las modalidades de falsedad documental que se describen en el tipo base del artículo 193 del Código Penal se refieren a la alteración del objeto material, mientras que los tipos de los artículos $1^{\circ}$ y $3^{\circ}$ de la Ley $\mathrm{N}^{\circ} 19.223$ aluden a las conductas de modificar o alterar, respectivamente.

En segundo lugar, se han presentado iniciativas legislativas tendientes a incluir explícitamente a los documentos electrónicos como objeto material de las falsedades documentales, destacando el Mensaje $\mathrm{N}^{\circ} 13-348$, de 25 de septiembre de 2002 (Boletín $\left.\mathrm{N}^{\circ} 3083-07\right)$ que, entre otros aspectos, pretendió incorporar en los tipos penales de falsedad "nuevas formas delictivas surgidas a partir del desarrollo de la informática"63. A éste se suma el Proyecto de Código Penal de 2014 (Boletín $\mathrm{N}^{\circ}$ 9.274-07), cuyo $\S 2$ del Título IX del Libro Segundo establece un artículo 403, que hace aplicables a los documentos electrónicos expedidos conforme a la ley el régimen de las falsedades documentales establecido en las disposiciones precedentes ${ }^{64}$. A nuestro juicio, tales iniciativas incluyen dentro de las falsedades documentales el mismo objeto material que se contempla en el delito de sabotaje informático, lo que sumado a la similitud de los comportamientos incriminados plantea un nuevo punto de conexión entre ambos ilícitos.

En tercer lugar, el artículo $7^{\circ}$ del Convenio sobre Ciberdelincuencia del Consejo de Europa (en adelante, "Convenio sobre Ciberdelincuencia"), publicado en el Diario Oficial el 28 de agosto de 2017, regula la denominada "falsificación informática", en relación con la cual establece: "Cada Parte adoptará las medidas legislativas y de otro tipo que resulten necesarias para tipificar como delito en su derecho interno la introducción, alteración, borrado o supresión deliberados e ilegítimos de datos informáticos que genere datos no auténticos con la intención de que sean tomados o utilizados a efectos legales como auténticos, con independencia de que los datos sean legibles e inteligibles directamente". Nuevamente se nota la conexión entre falsedades documentales y sabotaje informático, particularmente en la referencia que se efectúa a la alteración, borrado o supresión de datos.

\footnotetext{
${ }^{63}$ En concreto, la propuesta buscaba regular junto con las falsedades documentales de los artículos 193 y 197 del Código Penal las falsificaciones de documentos electrónicos, así como la clonación y adulteración de tarjetas de crédito. En cuanto a la falsedad de documentos electrónicos, se planteaba la incorporación de un inciso segundo al artículo 193, del siguiente tenor: "Con la misma pena se castigará al empleado público que, abusando de su oficio, forjare o alterare un documento público electrónico o incurriere, respecto de un instrumento público electrónico, en alguna de las falsedades previstas en los numerales $2^{\circ}, 3^{\circ}, 4^{\circ}$ y $7^{\circ}$ precedentes". Para un análisis de esta propuesta véase LONDOÑ, "Los Delitos", cit. nota n 50, pp. 186 y ss.

${ }^{64}$ Ya previamente el Anteproyecto de Código Penal de 2005 contemplaba, en el artículo 245, un precepto que hacía aplicables las disposiciones del Título X, De las Falsedades, a los documentos electrónicos expedidos conforme a la ley, en relación con los cuales se cometieran las respectivas falsedades. Véase "Anteproyecto de Código Penal Chileno de 2005, elaborado por la Comisión Foro Penal”, Revista Política Criminal, $\mathrm{n}^{\circ} 1$, pp. $1-92$, p. 53.
} 


\section{MAYER, Laura; VERA, Jaime "El documento como objeto material de las falsedades documentales y del sabotaje informático en el Derecho penal chileno".}

\subsection{Alteración de documentos electrónicos}

Desde el punto de vista del sentido y alcance del verbo "alterar", el Diccionario de la RAE establece cuatro acepciones del mismo, de las cuales las dos primeras resultan pertinentes para nuestro análisis. Así, alterar puede entenderse como "[c]ambiar la esencia o forma de algo", o bien, como "[e]stropear, dañar, descomponer"; mientras que "modificar" alude, en lo que aquí interesa, a "[t]ransformar o cambiar algo mudando alguna de sus características", así como a "[d]ar un nuevo modo de existir a la sustancia material". A nuestro modo de ver, ambos comportamientos no se diferencian en términos relevantes y pueden, consiguientemente, ser entendidos como sinónimos.

Pues bien ¿qué tipo o tipos penales resultan aplicables en caso que se altere un documento electrónico? Por una parte, podría entenderse satisfecho el delito de falsedad documental, en la medida en que se modifique la declaración del pensamiento contenida en el soporte electrónico, por ejemplo, fingiendo firmas (artículo 193 número 1 del Código Penal); modificando fechas (artículo 193 número 5 del Código Penal); o efectuando en el documento electrónico alteraciones o intercalaciones que hagan variar el sentido de dicha declaración (artículo 193 número 6 del Código Penal). Por otra parte, podría estimarse configurado el delito de sabotaje informático, si se modifica uno o más documentos electrónicos, hipótesis que puede subsumirse en la referencia a datos contenidos en un sistema de tratamiento automatizado de la información (artículos $1^{\circ}$ y $3^{\circ}$ de la Ley $\mathrm{N}^{\circ}$ 19.223).

En nuestra opinión, si bien puede existir una coincidencia material ${ }^{65}$ entre la alteración de un documento electrónico en el sentido de las falsedades documentales y la alteración de los datos en el sentido del sabotaje informático, desde un punto de vista valorativo resulta necesario diferenciar entre ambas hipótesis. En el primer caso se produce una afectación de la funcionalidad documental, o sea, una incidencia negativa en una o más de las funciones que cumplen los documentos en el tráfico jurídico (perpetuación, garantía y prueba). En el segundo caso se verifica una afectación de la funcionalidad informática, o sea, una incidencia negativa en una o más de las funciones que desempeñan los sistemas informáticos (almacenamiento, tratamiento y transferencia de datos); así como una afectación de otros intereses — - v. gr. la propiedad—, según la naturaleza de los datos. En virtud de lo expresado, es posible advertir desvalores de resultado diferenciables, lo que nos lleva a estimar que en este supuesto existe un concurso ideal entre alguna de las modalidades de falsedad documental y el sabotaje informático, que debe resolverse de acuerdo con lo establecido en el artículo 75 del Código Penal.

Así, por ejemplo, si se altera la base de datos del Ministerio Público, en la que consta información relativa a las investigaciones que dirige dicho organismo, modificando los datos de las personas que figuran como imputados y las actuaciones de investigación realizadas, se advierte una afectación de los siguientes intereses: Por una parte, en el plano

\footnotetext{
${ }^{65}$ Tal coincidencia material se produce por la identidad conceptual que es posible plantear entre la declaración del pensamiento humano como elemento integrante del documento (electrónico) y los datos. Véase el punto 1.2 .
} 


\section{Polít. crim. Vol. 14, No 27 (Julio 2019), Art. 12, pp. 419-455 [http://politcrim.com/wp-content/uploads/2019/05/Vol14N27A12.pdf]}

de las falsedades documentales, se incide negativamente en la función perpetuadora (porque se altera la declaración del pensamiento que contiene la base de datos), así como en la función de prueba (pues se afecta la posibilidad de acreditar fidedignamente el contenido de las mismas) ${ }^{66}$. Por otra parte, en el plano del sabotaje informático, se incide negativamente en las funciones de almacenamiento, tratamiento y transferencia de los datos alterados.

A la postura planteada supra podría objetársele el hecho de existir elementos comunes entre la funcionalidad documental y la funcionalidad informática, que pondrían en cuestión la independencia de ambos bienes jurídicos para los efectos de sustentar la tesis del concurso ideal de delitos. En efecto, es posible advertir un punto de contacto entre la función de perpetuación —en el caso de las falsedades documentales - y la función de almacenamiento —en el caso de los sistemas de tratamiento automatizado de la información-, ya que el almacenamiento de datos puede ser entendido como un supuesto de fijación indeleble del pensamiento humano, sólo que en el ámbito informático.

No obstante, las funciones que cumplen los documentos, por una parte, y las que desempeñan los sistemas informáticos, por la otra, exceden de la perpetuación y del almacenamiento, respectivamente. Asimismo, lo usual será que en virtud de la ejecución de las modalidades de falsedad documental y de sabotaje informático, ya descritas, se afecten funciones no coincidentes. Esto puede dar lugar a diversas combinaciones relativas a la ofensividad del comportamiento, en las que no exista identidad de bienes jurídicos, v. gr. se podría alterar un documento electrónico modificando la identidad de su otorgante o las declaraciones que éste efectúa. Tal conducta afecta la función de garantía o de prueba, en el ámbito de las falsedades, pero también —en tanto implica una alteración de datos - la función de almacenamiento, en el ámbito del sabotaje informático ${ }^{67}$.

Con todo, en el hipotético evento que se ejecute una conducta que implique una alteración de un documento electrónico que pueda calificarse como falsedad documental y sabotaje informático, pero que involucre únicamente una afectación de las funciones de perpetuación y almacenamiento, se configuraría un supuesto de concurso aparente de leyes penales, y no de concurso ideal como en los casos antes indicados. A nuestro entender, dicho concurso debería resolverse por aplicación del principio de alternatividad, imponiendo la figura que, en el caso concreto, acarree la pena más severa, captando con ello el mayor desvalor involucrado en el comportamiento ${ }^{68}$.

\footnotetext{
${ }^{66}$ Para que se incidiera negativamente en la función de garantía de los documentos electrónicos debería provocarse una ruptura en la relación entre autor y declaración del pensamiento realizada, ruptura que no advertimos en este supuesto, a menos que la alteración involucre atribuir el contenido de la misma a un sujeto diferente del Ministerio Público.

${ }^{67}$ Igualmente, como el delito de sabotaje informático aquí es entendido como una figura pluriofensiva, es posible que con la alteración del documento electrónico se afecten las funciones de garantía, perpetuación y prueba, en lo que respecta a las falsedades documentales; pero también algún bien jurídico (más) tradicional, v. gr. la propiedad, en lo que respecta al sabotaje informático.

${ }^{68}$ En esa línea POLITOFF; MATUS; RAMÍREZ, Lecciones, cit. nota n 30, pp. 450 y s.
} 


\section{MAYER, Laura; VERA, Jaime "El documento como objeto material de las falsedades documentales y del sabotaje informático en el Derecho penal chileno".}

\subsection{Destrucción (supresión), inutilización y ocultamiento de documentos electrónicos}

Desde el punto de vista del sentido y alcance del verbo "destruir", el Diccionario de la RAE establece dos acepciones respecto de dicha conducta que resultan de interés para el análisis que aquí se propone. Cuando se trata de un objeto que tiene una materialidad, destruir supone reducir a pedazos o a cenizas u ocasionar un grave daño. En cambio, si nos hallamos ante un objeto que no tiene una materialidad, destruir es deshacer o inutilizar. El comportamiento consistente en destruir se vincula con el de suprimir que, de acuerdo con el referido diccionario, importa hacer cesar o hacer desaparecer.

“Inutilizar", según el Diccionario de la RAE, significa hacer inútil, vano o nulo algo. En el fondo, se trata de tornar algo inservible o impedir que cumpla las funciones que normalmente desempeña. De ahí su cercanía e incluso sinonimia con el verbo "destruir".

Finalmente, para la voz "ocultar" el Diccionario de la RAE indica tres acepciones, de las cuales una es pertinente. Así, ocultar puede entenderse como esconder, tapar, disfrazar o encubrir a la vista. O bien — más allá de lo que establece dicho diccionario-, incluso como negar el acceso al documento o retenerlo ${ }^{69}$.

Todas las conductas aludidas tienen en común una afectación de las diversas funciones que constituyen los bienes jurídicos tutelados por las falsedades documentales y los delitos informáticos.

En efecto, cuando se destruye un documento electrónico desaparece el soporte que fija la declaración del pensamiento (función de perpetuación) y no resulta posible identificar a su autor ni acreditar su contenido en el tráfico jurídico documental (función de garantía y función de prueba). En el mismo sentido, cuando se destruye el documento electrónico desaparece el soporte que fija la declaración del pensamiento (función de almacenamiento) y deja de ser posible un procesamiento o una transmisión de datos informáticos (función de tratamiento y de transferencia de datos).

Algo parecido puede decirse del comportamiento consistente en inutilizar el documento electrónico, pues éste se relaciona, precisamente, con la idea de impedir que el documento cumpla las funciones que le son propias.

En cambio, como veremos, si se oculta un documento electrónico se incide negativamente tanto en las funciones que desempeñan los documentos como en las funciones que cumplen los sistemas informáticos, pero de una forma menos intensa que en las hipótesis de destrucción o inutilización.

En relación con las falsedades documentales, primeramente debe despejarse un problema relativo a la ausencia en el artículo 193 del Código Penal de una modalidad expresa que sancione la destrucción o supresión, o bien, la inutilización de un documento ${ }^{70}$.

\footnotetext{
${ }^{69}$ Así GARRIDO, Derecho penal, cit. nota ${ }^{\circ} 29$, p. 76.

${ }^{70}$ Este problema no se presenta en otros ordenamientos jurídicos que equiparan expresamente la supresión y la alteración documental, como es el caso del $§ 274$ del Código penal alemán. Véase PUPPE, Ingeborg, “§
} 


\section{Polít. crim. Vol. 14, No 27 (Julio 2019), Art. 12, pp. 419-455 [http://politcrim.com/wp-content/uploads/2019/05/Vol14N27A12.pdf]}

Como es sabido, la doctrina distingue entre falsedades propias e impropias ${ }^{71}$. Son falsedades propias las modalidades comisivas que importan una alteración de la verdad. Son falsedades impropias, por su parte, aquellas que envuelven una afectación del bien jurídico funcionalidad documental ${ }^{72}$, pero que no implican una alteración de la verdad en estricto sentido. Se trata fundamentalmente de las llamadas falsedades de uso, de destrucción o supresión, o de ocultación ${ }^{73-74}$.

La distinción entre falsedades propias e impropias es aplicable al ordenamiento jurídico chileno, pues el legislador consagra dentro de las falsedades documentales comportamientos que no son propiamente falsarios. Tal es el caso del artículo 193 número 8 del Código Penal, que castiga a quien oculte en perjuicio del Estado o de un particular un documento oficial.

En cuanto al sentido y alcance de dicha figura, la doctrina discute si en el referido precepto también se incluye la destrucción o supresión del documento. Según Etcheberry, la destrucción (supresión) de documentos debe sancionarse de acuerdo con el artículo 242 del Código Penal, si el documento es público y el agente un funcionario; según el artículo 193 número 8 , si el documento es oficial y el sujeto activo un particular; y en virtud del artículo 470 número 5 , si el documento es privado y la conducta corresponde a una defraudación ${ }^{75}$. En cambio, para Garrido la destrucción de documentos ha de castigarse de acuerdo con el artículo 242 del Código Penal, si el agente es un funcionario, y según el artículo 245, si el sujeto activo es un particular ${ }^{76}$.

En nuestro concepto, estas interpretaciones no resuelven satisfactoriamente el castigo de la destrucción o supresión documental en el Derecho chileno.

En cuanto a la eventual aplicación de los artículos 242 y 245 del Código Penal a la hipótesis de destrucción (supresión) de documentos, debe tenerse presente que éstos sancionan, entre otras cosas, la destrucción de documentos o papeles dentro del Párrafo 7

274", en: KINDHÄUSER, Urs; NEUMANN, Ulfrid; PAEFFGEN, Hans-Ullrich (edits.), Nomos Kommentar, Strafgesetzbuch, tomo 3, 4ª edición, Baden-Baden: Nomos, 2013, nm. 1 y ss.

${ }^{71}$ Para tal distinción véase, por ejemplo, VILLACAMPA, La falsedad, cit. nota n ${ }^{\circ}$ 8, p. 349.

${ }^{72}$ En esa línea BACIGALUPO, Enrique, "La reforma", cit. nota $n^{\circ} 1$, p. 1670, indica que, por ejemplo, la función de perpetuación del documento se ve afectada cuando éste es destruido o deteriorado, manifestándose además crítico de la forma cómo se resuelve el castigo de esta modalidad comisiva en el Código Penal actualmente vigente en España.

${ }^{73}$ Véase CARRARA, Francesco, Programa de Derecho criminal. Parte especial, vol. VII, trad. de José Ortega y Jorge Guerrero, Bogotá: Temis, 1964, § 3651, p. 277, con referencia a la supresión de documentos. Sin embargo, no todos están de acuerdo en la calificación de estas conductas como falsedades. Así, por ejemplo, para QUERALT, "La falsedad", cit. nota $\mathrm{n}^{\circ}$ 14, p. 1135, ni la destrucción ni la ocultación documental -a la que agrega la sustracción- pueden calificarse como falsedades, pues no constituyen alteraciones a la verdad.

${ }^{74}$ El tratamiento como falsedades documentales de estas conductas parece tener su origen en el Derecho romano. En esa línea, QUINTANO, Antonio, La falsedad documental, Madrid: Reus, 1952, p. 196, destaca que ya en un texto de Ulpiano se propugnaba la aplicación de la Lex Cornelia a los ocultadores de testamentos (qui testamentum amoverit, celaverit, eripuerit, deleverit, interleverit, subiecerit, recitaverit).

${ }^{75}$ Véase ETCHEBERRY, Derecho Penal, cit. nota n ${ }^{\circ}$ 31, p. 167.

${ }^{76}$ Véase GARRIDO, Derecho penal, cit. nota n 29, p. 76. 


\section{MAYER, Laura; VERA, Jaime "El documento como objeto material de las falsedades documentales y del sabotaje informático en el Derecho penal chileno".}

del Título V del Libro II del Código Penal, o sea, aquel que castiga la Infidelidad en la custodia de documentos. En tanto dichos preceptos contraponen "documentos" a "papeles", no impiden la subsunción de documentos electrónicos que, precisamente, pueden quedar abarcados por la referencia amplia efectuada a los "documentos". En otras palabras, dicho artículo no exige que el documento esté contenido en un papel, por lo que tales figuras pueden incluir, asimismo, comportamientos que afecten al documento electrónico. De otra parte, si bien tales conductas inciden negativamente en la función pública, lo hacen en términos relativamente insignificantes, razón que ha llevado a poner en duda la necesidad de su criminalización ${ }^{77}$ y justifica su exiguo castigo en comparación con otros delitos similares: reclusión menor en su grado máximo y multa de 21 a 25 UTM si del hecho resultare grave daño de la causa pública o de un tercero; o reclusión menor en sus grados mínimo a medio y multa de 11 a 20 UTM si no concurrieren las circunstancias expresadas. En esa línea, carecería de sentido que se sancionara más drásticamente la mera ocultación del documento - según las normas de las falsedades - que la destrucción o supresión del documento - según las normas de la infidelidad en la custodia de documentos-.

Sobre la posible utilización del artículo 470 número 5 del Código Penal para castigar casos de destrucción (supresión) de documentos, debe considerarse que éste sanciona a quien cometiere defraudaciones "sustrayendo, ocultando, destruyendo o inutilizando en todo o en parte algún proceso, expediente, documento u otro papel de cualquiera clase". Puesto que dicho artículo da a entender que el documento de que se trate debe estar materializado en un papel, no es posible aplicar dichas figuras a casos en los que se destruya (suprima) un documento electrónico. Más allá de esta dificultad relativa al objeto material, el delito en comento está regulado dentro del Párrafo 8 del Título IX del Libro II, esto es, aquel dedicado a las Estafas y otros engaños. Dicha ubicación sistemática permite concebirlo como un fraude especial, que afecta intereses patrimoniales ${ }^{78} \mathrm{y}$ hace aplicables las penas del artículo 467 que, como se sabe, dependen del monto de lo defraudado. A nuestro juicio, si bien son imaginables supuestos en que la conducta descrita en el tipo incida negativamente en intereses patrimoniales, la destrucción (supresión) de documentos se vincula mucho más claramente con la afectación de las funciones que desempeñan los documentos al interior del tráfico jurídico.

Tratándose de los tipos de los artículos 193 y 194 del Código Penal, ambos sancionan, entre otras conductas, la ocultación de documentos oficiales dentro del Párrafo 4 del Título IV del Libro II, o sea, el De la falsificación de documentos públicos o auténticos. De acuerdo con lo señalado supra, esos delitos contemplan referencias al concepto de documento, lo que permite subsumir en ellos — también - a los comportamientos que recaen sobre documentos electrónicos. Por otro lado, tales figuras inciden negativamente en la funcionalidad documental y se encuentran amenazadas — en coherencia con el bien jurídico que protegen - con una pena de presidio menor en su grado máximo a presidio mayor en su grado mínimo, en el caso del delito del artículo 193; y de presidio menor en sus grados medio a máximo, en el caso del delito del artículo 194.

\footnotetext{
${ }^{77}$ Así RODRÍGUEZ, Luis; OSSANDÓN, Magdalena, Delitos contra la función pública, reimpresión de la $2^{\mathrm{a}}$ edición, Santiago: Editorial Jurídica de Chile, 2011, p. 482.

${ }^{78}$ Así GARRIDO, Derecho penal, cit. nota n 29, p. 392.
} 


\section{Polít. crim. Vol. 14, № 27 (Julio 2019), Art. 12, pp. 419-455 [http://politcrim.com/wp-content/uploads/2019/05/Vol14N27A12.pdf]}

Teniendo presente lo dicho, debemos resolver si es posible sancionar la destrucción (supresión) de documentos electrónicos de acuerdo con la hipótesis de ocultación que prevé el numeral 8 del artículo 193 del Código Penal ${ }^{79}$.

En primer lugar, para determinar el castigo de la destrucción (supresión) de documentos ha de considerarse que la destrucción (supresión) de documentos electrónicos puede castigarse en virtud del delito de sabotaje informático (artículos $1^{\circ}$ y $3^{\circ}$ de la Ley $\mathrm{N}^{\circ} 19.223$ ). No obstante, entendiendo que dicha conducta también afecta los bienes jurídicos comprendidos en la regulación de las falsedades documentales (perpetuación, garantía y prueba), aplicar únicamente los tipos asociados a la criminalidad informática en este caso supondría dejar sin protección a los intereses relacionados con los delitos falsarios. A ello se agrega que la subsunción del comportamiento indicado en el sabotaje informático sólo resuelve la destrucción (supresión) de documentos electrónicos, no así la de documentos contenidos en papel. O sea, mientras que la destrucción (supresión) de documentos electrónicos podría castigarse a título de sabotaje informático, en principio no sería posible sancionar la destrucción (supresión) de documentos en papel a título de falsedad documental, por carecer el artículo 193 del Código Penal de una modalidad que castigue expresamente dicho comportamiento.

En segundo lugar, para determinar la sanción punitiva de la destrucción (supresión) de documentos debe tenerse presente que esa conducta es más grave que la mera ocultación de dicho soporte. En efecto, cuando se destruye (suprime) un documento se afectan todas las funciones que cumplen los documentos en el tráfico jurídico de una manera total, absoluta y definitiva. Consiguientemente, una vez destruido (suprimido) el documento deja de ser posible que éste satisfaga las funciones de perpetuación, garantía y prueba. En cambio, si sólo se oculta el documento, también se afectan todas las funciones que cumplen los documentos en el tráfico jurídico, pero de una manera menos intensa que en el caso de la destrucción. Por lo mismo, cuando se oculta el documento sigue siendo posible que éste desempeñe las funciones de perpetuación, garantía y prueba, por ejemplo, si el documento es encontrado o el agente lo vuelve a ingresar al tráfico jurídico. A la luz de lo señalado es que estimamos que no resulta conveniente, desde el punto de vista de una adecuada protección de la funcionalidad documental, dejar impune la destrucción (supresión) de documentos y que, por el contrario, ella debe quedar incluida dentro del comportamiento consistente en ocultarlos.

Dicha interpretación no contraría el sentido literal posible del término "ocultar". "Destruir", de acuerdo con lo señalado supra, implica, entre otras cosas, "deshacer", conducta que según el Diccionario de la RAE puede definirse como descomponer (primera acepción) o despedazar (quinta acepción), pero también como "[d]esaparecerse o desvanecerse de la vista" (novena acepción). Por eso es que el comportamiento consistente en destruir puede relacionarse, como ya se dijo, con el de suprimir o de hacer desaparecer. Y ocultar, de acuerdo con lo indicado al comienzo del presente apartado, importa esconder o encubrir a la vista.

\footnotetext{
${ }^{79}$ Aceptan la aplicación de dicho artículo en caso de ocultación seguida de destrucción, con perjuicio a terceros o al Fisco, POLITOFF; MATUS; RAMÍREZ, Lecciones, cit. nota n 30, p. 569.
} 


\section{MAYER, Laura; VERA, Jaime "El documento como objeto material de las falsedades documentales y del sabotaje informático en el Derecho penal chileno".}

Al planteamiento realizado supra podría objetársele el hecho de extender en demasía la interpretación de la conducta de ocultar documentos. No obstante, él permite salvar las graves incoherencias valorativas en el régimen penal de las falsedades documentales señaladas precedentemente. Con todo, teniendo en cuenta los reparos que puede generar la solución que aquí se propone, de lege ferenda resultaría recomendable que en una futura reforma de los delitos de falsedad se incluyera explícitamente el comportamiento consistente en destruir (suprimir) documentos, como de hecho se ha sugerido en algunas iniciativas legislativas recientes ${ }^{80}$.

Despejada la posibilidad de sancionar la destrucción (supresión) documental como una modalidad falsaria ¿qué tipo o tipos penales resultan aplicables en caso que se destruya un documento electrónico?

Por una parte, podría entenderse satisfecho el delito de falsedad documental, en la medida en que se destruya el documento electrónico (artículo 193 número 6 u 8 del Código Penal, según si el detrimento es parcial o total ${ }^{81}$ ). En este contexto, debe tenerse presente, que el detrimento parcial del documento electrónico puede identificarse con el daño del documento; v. gr. hacer supresiones a ciertos pasajes del mismo.

Por otra parte, podría estimarse configurado el delito de sabotaje informático, si se destruye uno o más documentos electrónicos, hipótesis que puede subsumirse dentro de la referencia a datos contenidos en un sistema de tratamiento automatizado de la información (artículos $1^{\circ}$ y $3^{\circ}$ de la Ley $\mathrm{N}^{\circ} 19.223$ ).

A nuestro juicio, no obstante puede verificarse una coincidencia material entre la destrucción de un documento electrónico en el sentido de las falsedades documentales y la destrucción de los datos en el sentido del sabotaje informático, desde un punto de vista valorativo resulta necesario diferenciar entre ambos supuestos. En efecto, en relación con las falsedades documentales, cuando se destruye un documento electrónico se incide negativamente en las funciones de perpetuación, garantía y prueba de los documentos, o sea, en todas las funciones que cumplen los documentos al interior del tráfico jurídico. Si se daña el documento electrónico, en cambio, puede afectarse una o más de dichas funciones, dependiendo del elemento del documento que resulte dañado. Por su parte, en relación con el sabotaje informático, si se destruye un documento electrónico se incide negativamente en las funciones de almacenamiento, tratamiento y transferencia de datos, esto es, en todas las funciones que desempeñan los sistemas informáticos; y se produce una afectación de otros intereses — v. gr. la propiedad—, dependiendo del carácter del documento electrónico. Si se daña el documento electrónico, por su parte, es posible incidir negativamente en una o más de dichas funciones, según el elemento del documento que resulte dañado; fuera de la

\footnotetext{
${ }^{80}$ En esa línea, correctamente, el Proyecto de Código Penal del año 2014, Boletín n ${ }^{\circ} 9274-07$, ingresado el 10 de marzo de 2014, consagra expresamente la modalidad de destrucción del documento en el artículo 402, equiparando este comportamiento a la inutilización u ocultación del documento. Por su parte, el artículo 403 del mismo Proyecto hace aplicable dicha figura a los documentos electrónicos.

${ }^{81}$ Estimamos que este es otro argumento para incluir la destrucción documental en el numeral 8 del artículo 193 del Código Penal. En ese sentido, constituiría una contradicción valorativa sancionar el daño o detrimento parcial del documento electrónico de acuerdo con el artículo 193 número 6, pero dejar impune la destrucción total, absoluta y definitiva del documento electrónico.
} 


\section{Polít. crim. Vol. 14, No 27 (Julio 2019), Art. 12, pp. 419-455 \\ [http://politcrim.com/wp-content/uploads/2019/05/Vol14N27A12.pdf]}

afectación de otros intereses — - v. gr. la propiedad-, dependiendo del carácter del documento electrónico. En virtud de lo expresado, es posible advertir nuevamente dos desvalores de resultado diferenciables, lo que nos lleva a estimar que en este caso también existe un concurso ideal entre la falsedad documental del artículo 193 número 8 del Código Penal y el sabotaje informático, que debe resolverse según lo dispuesto en el artículo 75 del Código Penal.

Así, por ejemplo, si se destruye la base de datos del Servicio de Impuestos Internos, en la que consta información relativa a las declaraciones de impuestos que mantiene dicho organismo, se advierte una afectación de los siguientes intereses: Por una parte, en el plano de las falsedades documentales, se incide negativamente en la función perpetuadora, porque desaparece el soporte documental y con ello la declaración del pensamiento en él contenida. También se afecta la función de garantía, pues ya no es posible identificar al autor de la declaración documentada. Finalmente, se incide negativamente en la función de prueba, porque deja de ser posible utilizar el soporte documental para acreditar su contenido al interior del tráfico. Por otra parte, en el plano del sabotaje informático, se afecta la función de almacenamiento, porque desaparecen los datos, lo que además impide procesarlos o transmitirlos en el futuro (función de tratamiento y de transferencia de datos).

Si se daña el documento electrónico, esto es, si existe un detrimento parcial del documento, puede aplicarse el tipo de falsedad del artículo 193 número 6 del Código Penal (en concurso ideal con el sabotaje informático), en la medida en que se altere el sentido de la declaración en él contenida. De suerte que si ello no acontece, el comportamiento en cuestión sólo podría subsumirse en el tipo de sabotaje informático, siempre que el daño para los datos tenga relevancia jurídico penal.

En el mismo sentido de lo que se afirmó supra, en el hipotético evento que se ejecute una conducta que implique un detrimento parcial del documento electrónico que pueda calificarse como falsedad documental y sabotaje informático, pero que importe únicamente una afectación de las funciones de perpetuación y almacenamiento, también se configuraría un supuesto de concurso aparente de leyes penales, y no de concurso ideal. En nuestra opinión, dicho concurso debería resolverse de igual modo, por aplicación del principio de alternatividad, imponiendo la figura que, en el caso concreto, acarree la pena más severa, captando con ello el mayor desvalor involucrado en el comportamiento.

\subsection{Uso de un software malicioso y su relación con el documento electrónico}

El empleo de programas maliciosos se ha vuelto un medio frecuente de comisión de diversos delitos informáticos ${ }^{82}$, entre ellos el sabotaje informático. En el caso de este último delito, el uso de un software malicioso puede incidir negativamente en la propia red

\footnotetext{
${ }^{82}$ Véase KOCHHEIM, Dieter, Cybercrime und Strafrecht in der Informations- und Kommunikationstechnik, München: Beck, 2015, pp. 612 y s. Con referencia al sabotaje informático MALEK, Klaus; POPP, Andreas, Strafsachen im Internet, $2^{\text {a }}$ edición revisada, Heidelberg: C. F. Müller, 2015, nm. 187; con énfasis en el fraude informático CLOUGH, Jonathan, Principles of Cybercrime, Cambridge: Cambridge University Press, 2010, p. 32 .
} 


\section{MAYER, Laura; VERA, Jaime "El documento como objeto material de las falsedades documentales y del sabotaje informático en el Derecho penal chileno".}

computacional, pero también en datos ${ }^{83} \mathrm{y}$, con ello, en documentos electrónicos. De esta forma, surge la interrogante relativa a qué tipo penal correspondería aplicar cuando, a través de un programa malicioso, se destruyen o alteran documentos electrónicos.

Asumiendo que los datos pueden expresar información y que, desde este punto de vista, implican una declaración del pensamiento humano relevante para efectos del concepto de documento; y considerando asimismo que es posible sancionar además de la alteración de documentos su destrucción como falsedad documental - de acuerdo con lo afirmado supra-, habría en este caso un concurso ideal entre alguna de las modalidades de falsedad documental y el sabotaje informático. En esa línea, se produce una afectación de una o más de las funciones que cumplen los documentos en el tráfico jurídico (perpetuación, garantía y prueba). Además, se incide negativamente en la funcionalidad informática, o sea, se afecta una $o$ más de las funciones que desempeñan los sistemas informáticos (almacenamiento, tratamiento y transferencia de datos); sin perjuicio de la vulneración de otros intereses - - . gr. la propiedad-, dependiendo del carácter del documento electrónico. En suma, nuevamente es posible advertir la concurrencia de desvalores de resultado diferenciables, lo que nos lleva a sostener que también en este supuesto existe un concurso ideal de delitos, que debe resolverse de acuerdo con lo establecido en el artículo 75 del Código Penal.

Reconociendo la relevancia que se le atribuye a los programas maliciosos respecto de la ejecución de delitos informáticos, el Convenio sobre Ciberdelincuencia regula en su artículo $6^{\circ}$ el "abuso de los dispositivos". Así, se establece que cada Parte adoptará las medidas que resulten necesarias para tipificar como delito la puesta a disposición deliberada e ilegítima de cualquier dispositivo, incluido un programa informático, concebido o adaptado principalmente para la comisión de cualquiera de los delitos previstos en los artículos $2^{\circ}$ a $5^{\circ}$, o sea, acceso ilícito, interceptación ilícita, ataques a la integridad de los datos o ataques a la integridad del sistema. Dicho Convenio dispone asimismo el deber de tipificar, entre otras, la posesión deliberada e ilegítima de programas informáticos con intención de que sean utilizados para llevar a cabo cualquiera de los delitos regulados en los artículos $2^{\circ}$ a $5^{\circ}$ del Convenio sobre Ciberdelincuencia ${ }^{84}$.

El castigo penal de la simple puesta a disposición y sobre todo de la mera posesión de un software malicioso - a diferencia del uso de dicho programa como medio de comisión de falsedades documentales o sabotaje informático- importa un adelantamiento excesivo de las barreras de protección del Derecho penal ${ }^{85}$. En efecto, dicha hipótesis supone elevar a la categoría de delito autónomo un acto preparatorio de las figuras señaladas y, en general, de

\footnotetext{
${ }^{83}$ Véase DE LA MATA, Norberto; HERNÁNDEZ, Leyre, "El delito de daños informáticos: una tipificación defectuosa", Estudios Penales y Criminológicos, vol. XXIX (2009), pp. 311-362, p. 313.

${ }^{84}$ Sobre ello véase, por ejemplo, GILLESPIE, Alisdair, Cybercrime: Key Issues and Debates, London-New York: Routledge, 2016, pp. 57 y s.

${ }^{85}$ En esa línea, aunque menos enfáticos, DE LA MATA, Norberto; HERNÁNDEZ, Leyre, "Un ejemplo de delitos informáticos: delitos contra sistemas y datos en el Código penal español ¿delitos de daños?”, en: DE LA CUESTA, José Luis (dir.), Derecho penal informático, Cizur Menor: Aranzadi, 2010, pp. 201-246, p. 211. Que se trate de actos "potencialmente peligrosos" (KIEFER, Mariana, "Daño informático", en: DUPUY, Daniela [dir.], Cibercrimen, Montevideo-Buenos Aires: B de f, 2016, pp. 313-344, p. 319) no nos parece suficiente para fundamentar el castigo penal autónomo de los referidos supuestos.
} 


\section{Polít. crim. Vol. 14, No 27 (Julio 2019), Art. 12, pp. 419-455 \\ [http://politcrim.com/wp-content/uploads/2019/05/Vol14N27A12.pdf]}

los delitos informáticos. A ello debe agregarse lo criticable que resulta sancionar penalmente la sola "posesión" de objetos, en tanto ésta, según un sector de la doctrina, no implica la realización de comportamiento humano alguno ${ }^{86}$, sino un simple estado de cosas. La importancia relativa del medio comisivo no alcanza a justificar político-criminalmente la creación de un delito en el que todavía no se advierte una afectación relevante de los bienes jurídicos que podrían estar involucrados en casos como los descritos.

Afortunadamente el Convenio sobre Ciberdelincuencia permite a las Partes reservarse el derecho a no tipificar como delito la mera posesión de un software malicioso, reserva que la República de Chile de hecho planteó (véase reserva b) de dicho Convenio). Gracias a ello, el legislador nacional no se encuentra obligado a castigar penalmente la sola posesión de esa clase de programas y si la sanciona, no podrá hacerlo bajo pretexto de que el aludido instrumento internacional así se lo impone. En cambio, la simple puesta a disposición de un software malicioso en los términos que establece el Convenio sobre Ciberdelincuencia sí debería tipificarse como delito, caso en el que se generarían las dificultades políticocriminales ya indicadas.

\subsection{Forjamiento del documento electrónico: ¿un caso de impunidad?}

Como es sabido, se discute si puede calificarse como falsedad documental el forjamiento o creación ex novo de un documento de carácter mendaz. A pesar de que resulta evidente que dicho comportamiento es capaz de afectar gravemente las tres funciones que desempeñan los documentos (perpetuación, garantía y prueba), las conductas previstas en el artículo 193 del Código Penal suponen que el agente ejecute el comportamiento falsario sobre un documento preexistente, el que es alterado materialmente o sobre el cual se vierte un contenido inveraz. Contrariamente, dicho precepto no efectúa referencias a la confección de un documento íntegramente falso.

\footnotetext{
${ }^{86}$ Desde un punto de vista más general STRUENSEE, Eberhard, "Besitzdelikte", en: SAMSON, Erich (edit.), Festschrift für Gerald Grünwald zum siebzigsten Geburtstag, Baden-Baden: Nomos, 1999, pp. 713 -729, p. 713; con matices ECKSTEIN, Ken, "Grundlagen und aktuelle Probleme der Besitzdelikte - EDV, EU, Strafrechtsänderungsgesetze, Konkurrenzen”, Zeitschrift für die gesamte Strafrechtswissenschaft, vol. 117 (2005), pp. 107-142, p. 110, pp. 112 y ss. De otra opinión, en cambio, COX, Juan Pablo, Delitos de posesión. Bases para una dogmática, Montevideo-Buenos Aires: B de f, 2012, p. 121 y passim, quien entiende que poseer supone desplegar cierto poder o control sobre un objeto. En todo caso, entre los que consideran que poseer sí implica una conducta (penalmente relevante) se dividen las opiniones, fundamentalmente entre quienes creen que se trata de una conducta activa (véase cit. p. 142) y quienes estiman que poseer constituye un comportamiento omisivo (en favor de su comprensión como hipótesis de comisión por omisión, por ejemplo, PASTOR, Nuria, Los delitos de posesión y los delitos de estatus: una aproximación político - criminal y dogmática, Barcelona: Atelier, 2005, p. 39). La crítica a los delitos de posesión no se limita a lo señalado y abarca, asimismo, su legitimación político-criminal, sobre todo si se considera que ellos no parecen afectar (directamente) bien jurídico alguno (sobre ello véase, por ejemplo, ROXIN, Claus, "Los delitos de tenencia", en: SCHROEDER, Friedrich-Christian; ECKSTEIN, Ken; FALCONE, Andrés [coords.], Delitos de posesión o tenencia, Buenos Aires: Ad hoc, 2016, pp. 143-163, pp. 151 y ss., quien, no obstante, distingue entre diversos objetos poseídos para efectos de justificar la intervención punitiva en este ámbito); así como su carácter permanente y de consiguiente imprescriptibilidad de la acción penal (respecto de este asunto véase GUZMÁN, José Luis, "Evaluación y racionalización de la reforma de los delitos contra la libertad sexual", Revista de Ciencias Sociales, n 68 [2016], pp. 105-136, p. 117, n. 22).
} 


\section{MAYER, Laura; VERA, Jaime "El documento como objeto material de las falsedades documentales y del sabotaje informático en el Derecho penal chileno".}

Lo expresado ha conducido a un sector importante de nuestra doctrina a afirmar la atipicidad del forjamiento de un documento mendaz. Así, según Garrido, no es posible incluir la creación ex novo de un documento falso en alguna de las hipótesis del artículo 193 del Código Penal, sin perjuicio de su punibilidad como fraude o estafa, si con ello se

busca inducir a error a otro, provocándole un perjuicio patrimonial ${ }^{87}$. En una dirección similar, Etcheberry sostiene que la única posibilidad de incriminar dicha conducta supone que un particular forje un documento a través de la imitación de la letra o firma del funcionario competente para emitirlo, en cuyo caso debería aplicarse el artículo 193 número 1. Por el contrario, el forjamiento íntegro no sería factible si lo comete el funcionario encargado de extender el documento, pues éste tendría siempre la genuinidad de provenir de una autoridad legítima ${ }^{88-89}$.

A nuestro juicio, a diferencia de lo indicado respecto del castigo de la destrucción (supresión) del documento con la figura de ocultación (artículo 193 número 8 del Código Penal), tratándose del forjamiento no es posible imponer las modalidades falsarias previstas en el artículo 193, pues el sentido de ellas, efectivamente, es que se cometa falsedad en un documento ya existente. La única excepción que divisamos a esta idea es la hipótesis del artículo 193 número 7 del Código Penal, en la que puede quedar incluido el forjamiento de la copia fehaciente de un documento supuesto y que sólo es aplicable a funcionarios que, en su calidad de ministros de fe, pueden dar copias autorizadas obtenidas de las matrices de los documentos que custodian, v. gr. notarios, archiveros y conservadores.

${ }^{87}$ GARRIDO, Derecho penal, cit. nota $\mathrm{n}^{\circ} 29$, p. 78 . El mismo autor se lamenta que esta postura no haya sido la de la jurisprudencia nacional, que no ha visto obstáculos para criminalizar dicho supuesto. En contra de la opinión de Garrido se pronuncia LABATUT, Derecho penal, cit. nota $n^{\circ} 30$, p. 56, para quien el forjamiento quedaría cubierto por el artículo 193 número 1 del Código Penal, aunque no explicita las razones para arribar a esta conclusión.

${ }^{88}$ ETCHEBERRY, Derecho Penal, cit. nota ${ }^{\circ} 31$, p. 165.

${ }^{89}$ Las divergencias doctrinales anotadas también se evidencian en la jurisprudencia reciente de nuestros tribunales. Se puede citar como ejemplo de ello dos sentencias emanadas de un mismo tribunal, que durante los últimos años ha emitido decisiones contrapuestas con respecto al tratamiento penal del forjamiento de un documento falsificado. En efecto, una primera sentencia de la Corte de Apelaciones de Valparaíso, de fecha 5 de enero de 2006, causa rol $\mathrm{N}^{\circ} 1373-2005$, se pronuncia sobre el forjamiento de un cheque, esto es, un instrumento mercantil, cuya falsedad está sancionada en el artículo 197 inciso $2^{\circ}$ del Código Penal. Esta disposición, a su vez, se remite al artículo 193 del referido Código. En el fallo se absolvió al imputado bajo el argumento de que este último precepto no establece una modalidad comisiva que capte el forjamiento íntegro de un documento. En resumen, las razones esgrimidas por la Corte se fundan en la tesis sostenida por Garrido y Etcheberry, quienes son citados expresamente en el fallo (considerando décimo octavo). De este modo, siendo atípica dicha modalidad como delito falsario, sólo podría castigársele como estafa, que es la calificación por la que se opta en definitiva (considerando vigésimo primero). Posteriormente, la misma Corte, con fecha 31 de agosto de 2011, en causa rol $N^{\circ} 851-2011$, se pronunció sobre la falsedad en virtud del forjamiento de una licencia de conducir, que es un hecho sancionado de manera específica en la Ley de Tránsito. Según se lee en su considerando cuarto, que cita otros fallos de la Corte Suprema y tiene en cuenta la remisión que el artículo 194 efectúa al artículo 193 del Código Penal, la Corte entendió que la fabricación y el forjamiento completo de un documento sí estarían sancionados en las modalidades descritas por esta última norma. 


\section{Polít. crim. Vol. 14, No 27 (Julio 2019), Art. 12, pp. 419-455 [http://politcrim.com/wp-content/uploads/2019/05/Vol14N27A12.pdf]}

El castigo excepcional de la creación ex novo de un documento mendaz se ve confirmado por la existencia de otros delitos falsarios que consagran explícitamente el forjamiento, como es el caso de partes telegráficos ${ }^{90}$ y pasaportes ${ }^{91}$.

Según nuestra opinión, todo lo dicho respecto del documento en papel es perfectamente aplicable al documento electrónico. Refuerza lo señalado el hecho que en el pasado se haya presentado un proyecto de ley, que buscaba sancionar el forjamiento de un documento electrónico $^{92}$, lo que implicaba un reconocimiento tácito de la atipicidad de dicha conducta.

De otro lado, el forjamiento de un documento electrónico de carácter mendaz tampoco parece subsumible en alguno de los tipos de la Ley $\mathrm{N}^{\circ} 19.223$. Por una parte, la única conducta del delito de sabotaje informático que remotamente podría vincularse con este supuesto es la consistente en modificar el funcionamiento de un sistema de tratamiento automatizado de la información, o sus partes o componentes (artículo $1^{\circ}$ inciso primero). Sin embargo, como señalamos precedentemente, modificar supone transformar algo, lo que importa que se esté incidiendo en algún elemento ya existente del sistema. Por otra parte, el forjamiento podría relacionarse, aunque de forma muy indirecta, con el espionaje informático (artículo $2^{\circ}$ ) cuando — previamente - se actúa con el ánimo de conocer indebidamente de la información contenida en un sistema de tratamiento de la misma, accediendo a él. Dado que el acceso (indebido) al sistema puede entenderse como un comportamiento implicado en la comisión de los delitos informáticos en general ${ }^{93-94}$, podría igualmente asumirse que concurre respecto de aquellas conductas que suponen forjar un documento electrónico. No obstante, como también ocurre a propósito de otros delitos informáticos, el solo acceso (indebido) no es capaz de captar el desvalor subyacente a las falsedades o al sabotaje informático.

\section{Conclusiones}

La definición de aquello que debe considerarse como documento para efectos penales ha estado muy ligada a la dogmática de los delitos de falsedad documental, figuras en que la conducta falsaria debe recaer, justamente, sobre dicho objeto material. Por ello, para

${ }^{90}$ Que, en todo caso, ha perdido aplicación en virtud del desuso en el que ha caído dicha forma de comunicación a distancia.

${ }^{91}$ Esta situación podría conducir a incoherencias valorativas, por ejemplo, que quien forje una escritura pública (falsa) quede impune, pero sí se castigue a quien forje un parte telegráfico (falso). Por tal motivo, resultaría preferible que en una futura revisión de los tipos de falsedad documental -en la medida en que se mantenga una sistemática casuística-, se incluya una figura típica que capte el forjamiento de un documento mendaz. En relación con este punto el Código Penal español, en su artículo 390.1.2, prevé expresamente una modalidad falsaria que sanciona a quien simule un documento en todo o parte de modo que induzca a error en cuanto a su autenticidad. Tal hipótesis fue incorporada por el legislador hispano con la reforma de 1944, precisamente, para salvar las dudas que generaba el tratamiento penal de la creación $a b$ initio de un documento apócrifo. Respecto de este asunto véase CASAS, El delito, cit. nota n 15, p. 288.

${ }^{92}$ Sobre ello véase LONDOÑO, "Los Delitos", cit. nota n 50 , p. 187.

${ }^{93}$ En esa línea ya HUERTA, Marcelo; LÍBANO, Claudio, Delitos informáticos, Santiago: Editorial Jurídica ConoSur, 1996, pp. 168 y s.; también MOSCOSO, Romina, "La Ley 19.223 en general y el delito de hacking en particular", Revista Chilena de Derecho y Tecnología, vol. 3, $\mathrm{n}^{\circ} 1$ (2014), pp. 11-78, p. 29 con referencias ulteriores.

$94 \mathrm{~V}$. gr. para destruir o modificar datos contenidos en un sistema de tratamiento automatizado de la información podría ser necesario acceder indebidamente a dicho sistema. 


\section{MAYER, Laura; VERA, Jaime "El documento como objeto material de las falsedades documentales y del sabotaje informático en el Derecho penal chileno".}

precisar el concepto de documento desde una perspectiva penal puede partirse del bien jurídico protegido por los delitos de falsedad documental que, a nuestro juicio, corresponde a la triple funcionalidad documental, o sea, a la función de perpetuación, garantía y prueba de los documentos.

Actualmente se discute si acaso el documento debe identificarse o no con un (papel) escrito. A pesar de que la mayoría de la doctrina chilena sigue inclinándose por una concepción restringida de documento, estimamos preferible adoptar un concepto amplio, que no identifique al documento necesariamente con un (papel) escrito. Por un lado, en el moderno tráfico jurídico el soporte escrito ha dejado de ocupar el lugar que tenía al dictarse el Código Penal, abriendo paso a otros, v. gr. los electrónicos. Por otra parte, la ausencia de un concepto penal de documento a nivel positivo lleva a considerar lo dispuesto en normas extrapenales, en las que se advierte una clara tendencia a ampliar la noción de documento.

El objeto material de las falsedades documentales puede ser un documento escriturado (en papel) o un documento electrónico. En ese sentido, y en contra de lo que plantea un sector de la doctrina, no es efectivo que las modalidades típicas del artículo 193 del Código Penal requieran que el agente opere siempre sobre un (papel) escrito, lo que abre la posibilidad a que el comportamiento recaiga en documentos de otra índole.

De acuerdo con la normativa extrapenal aplicable a los documentos es posible sostener que hay documentos electrónicos públicos y privados, debiendo castigarse su falsedad de acuerdo con los respectivos tipos penales (artículos 193 y ss. del Código Penal chileno), lo que tiene incidencia en relación con la penalidad aplicable a cada uno de ellos.

El objeto material del sabotaje informático, regulado en la Ley $\mathrm{N}^{\circ} 19.223$, puede ser un documento electrónico, no así un documento contenido en papel. De esta manera, el delito de sabotaje informático corresponde a un caso de desmaterialización del objeto material sobre el que recae la conducta típica, ya que ésta se dirige fundamentalmente contra el software o soporte lógico de un sistema informático.

Las conductas que sólo involucran destrucción o inutilización de un hardware deben castigarse mediante los tipos de daños del Código Penal. Los comportamientos que implican destrucción o inutilización de un hardware que contiene datos, pero que no resultan destruidos o inutilizados han de sancionarse con el artículo $1^{\circ}$ inciso primero de la Ley $\mathrm{N}^{\circ}$ 19.223; los que suponen destrucción o inutilización de un hardware que contiene datos que sí resultan destruidos o inutilizados deben castigarse con el artículo $1^{\circ}$ inciso segundo de la referida ley; mientras que los que importan únicamente destrucción o inutilización de datos han de sancionarse a través del artículo $3^{\circ}$ de la Ley $\mathrm{N}^{\circ} 19.223$. Tal interpretación parte de la vinculación sistemática entre las figuras de sabotaje informático, así como entre éstas y las hipótesis de daños; y tiene en cuenta las diferencias penológicas que ellas conllevan, las que a su vez se explican en su distinta ofensividad.

Si se realiza un análisis análogo al que se efectúa respecto de las falsedades documentales, cabe sostener que los casos de impedimento, obstaculización, modificación, alteración o daño que castiga el sabotaje informático han de tener una cierta relevancia, esto es, referirse a los extremos principales del funcionamiento del sistema informático, apuntar a los 


\section{Polít. crim. Vol. 14, № 27 (Julio 2019), Art. 12, pp. 419-455 [http://politcrim.com/wp-content/uploads/2019/05/Vo114N27A12.pdf]}

aspectos centrales de la declaración del pensamiento humano que expresa el documento electrónico, entre otros.

La Ley $\mathrm{N}^{\circ} 19.223$ no diferencia entre documentos electrónicos públicos o privados para efectos de la penalidad aplicable al sabotaje informático. El hecho que con él se incida sobre un documento electrónico de carácter público - en comparación con el documento electrónico privado - , puede considerarse por el juez, pero sólo en el acotado margen que le ofrece el artículo 69 del Código Penal.

Por regla general, la alteración de un documento electrónico da lugar a un concurso ideal entre alguna de las modalidades de falsedad documental y el sabotaje informático, pues ambos supuestos afectan bienes jurídicos distintos. Pero, si el comportamiento en cuestión sólo implica incidir negativamente en las funciones de perpetuación y almacenamiento, habrá un concurso aparente de leyes penales, que debería resolverse según el principio de alternatividad, aplicando la figura que, en el caso concreto, acarree la pena más alta.

Es posible castigar la destrucción (supresión) de documentos electrónicos en virtud del delito de sabotaje informático y de las falsedades documentales. En relación con estas últimas, destruir puede entenderse como hacer desaparecer, comportamiento que se vincula directamente con el de ocultar, reconocido de forma expresa en el artículo 193 número 8 del Código Penal. No obstante, estimamos recomendable, de lege ferenda, incluir explícitamente la conducta consistente en destruir (suprimir) documentos en una futura reforma de los delitos de falsedad documental.

La destrucción de un documento electrónico da lugar a un concurso ideal entre la falsedad documental del artículo 193 número 8 del Código Penal y el sabotaje informático, pues ambos supuestos afectan bienes jurídicos distintos. El daño parcial de un documento electrónico puede suponer un concurso ideal entre la falsedad documental del artículo 193 número 6 del Código Penal y el sabotaje informático, en la medida en que se altere el sentido de la declaración en él contenida, pues, si ello no ocurre, él únicamente podrá castigarse como sabotaje informático. Ahora bien, si el daño parcial sólo implica incidir negativamente en las funciones de perpetuación y almacenamiento habrá un concurso aparente de leyes penales, que debería resolverse según el principio de alternatividad, aplicando la figura que, en el caso concreto, acarree la pena más alta.

Por último, el forjamiento de un documento electrónico falso es una conducta atípica, que no puede subsumirse en las falsedades documentales -que suponen actuar sobre un documento preexistente- ni en los delitos informáticos de la Ley $\mathrm{N}^{\circ}$ 19.223. La única excepción que divisamos a esta idea es la hipótesis del artículo 193 número 7 del Código Penal, en la que es posible incluir el forjamiento de la copia fehaciente de un documento supuesto y que sólo es aplicable a funcionarios que, en su calidad de ministros de fe, pueden dar copias autorizadas obtenidas de las matrices de los documentos que custodian. 


\section{Bibliografía}

ARMENTEROS, Miguel, Los delitos de falsedad documental, Granada: Comares, 2011.

BACIGALUPO, Enrique, "Documentos electrónicos y delitos de falsedad documental", Revista Electrónica de Ciencia Penal y Criminología, 04-12 (2002), pp. 1-17, en: http://criminet.ugr.es/recpc/recpc_04-12.pdf [visitado el 10.11.2017].

BACIGALUPO, Enrique, "La reforma de las falsedades documentales", La Ley: Revista jurídica española de doctrina, jurisprudencia y bibliografía, nº 1 (1996), pp. 1668 1672.

BENÉYTEZ, Luis, "Bien jurídico protegido: Concepto de documento público. Las conductas falsarias del art. 302 del CP", en: Las falsedades documentales. Libro homenaje a Enrique Ruiz Vadillo, Granada: Comares, 1994, pp. 37-76.

BINDING, Karl, Lehrbuch des Gemeinen Deutschen Strafrechts, Besonderer Teil, tomo II, $2^{a}$ edición aumentada, Leipzig: Engelmann, 1904.

BONÉ, Juan; SOTERAS, Rafael, De las falsedades. Comentario a los artículos 386 al 403 del Código Penal de 1995, Barcelona: Bosch, 2000.

CALlE, María Victoria, Falsedades documentales no punibles, Madrid: Editoriales de Derecho Reunidas, 1998.

CALLE, María Victoria, "Teoría general sobre la falsedad documental y selección de jurisprudencia sobre la falsedad documental con especial referencia al documento mercantil, I y II", Cuadernos de Política Criminal, no 53 (1994), pp. 703-740.

CAMARGO, César, "Falsificación de documentos públicos", Anuario de Derecho Penal y Ciencias Penales, $\mathrm{n}^{\circ} 3$ (1957), pp. 519-538.

CANELO, Carola; ARRIETA, Raúl; MOYA, Rodrigo; ROMO, Rodrigo, "El documento electrónico. Aspectos procesales", Revista Chilena de Derecho Informático, $\mathrm{n}^{\circ} 4$ (2004), pp. 81-106.

CARNELUTTI, Francesco, Teoria del falso, Padova: Cedam, 1935.

CARRARA, Francesco, Programa de Derecho criminal. Parte especial, vol. VII, trad. De José Ortega y Jorge Guerrero, Bogotá: Temis, 1964.

CARRERAS, Eduardo, Los Delitos de Falsedades Documentales, Buenos Aires: Ad-hoc, 1998.

CASAS, Enrique, El delito de falsedad en documento privado, Barcelona: Bosch, 1984.

CLOUGH, Jonathan, Principles of Cybercrime, Cambridge: Cambridge University Press, 2010.

COBO DEL ROSAL, Manuel; VIVES, Tomás, Derecho Penal. Parte General, $5^{\text {a }}$ edición, Valencia: Tirant lo blanch, 1999.

CORCOY, Mirentxu, "Problemática de la persecución penal de los denominados delitos informáticos: particular referencia a la participación criminal y al ámbito espacio temporal de comisión de los hechos", Eguzkilore, n 21 (2007), pp. 7-32.

COX, Juan Pablo, Delitos de posesión. Bases para una dogmática, Montevideo-Buenos Aires: B de f, 2012.

CREUS, Carlos, Falsificación de documentos en general, $3^{\mathrm{a}}$ edición actualizada y ampliada, Buenos Aires: Astrea, 1999. 
DE LA MATA, Norberto; HERNÁNDEZ, Leyre, "El delito de daños informáticos: una tipificación defectuosa", Estudios Penales y Criminológicos, vol. XXIX (2009), pp. $311-362$.

DE LA MATA, Norberto; HERNÁNDEZ, Leyre, "Un ejemplo de delitos informáticos: delitos contra sistemas y datos en el Código penal español ¿delitos de daños?”, en: DE LA CUESTA, José Luis (dir.), Derecho penal informático, Cizur Menor: Aranzadi, 2010, pp. 201-246.

ECKSTEIN, Ken, "Grundlagen und aktuelle Probleme der Besitzdelikte - EDV, EU, Strafrechtsänderungsgesetze, Konkurrenzen”, Zeitschrift für die gesamte Strafrechtswissenschaft, vol. 117 (2005), pp. 107-142.

ETCHEBERRY, Alfredo, Derecho Penal. Parte Especial, tomo IV, reimpresión de la $3^{\text {a }}$ edición, Santiago: Editorial Jurídica de Chile, 2010.

ETCHEBERRY, Alfredo, "El objeto material del delito de falsedad documental: documentos y sus clases", Revista de Ciencias Penales, tomo XX (1961), pp. 219-240.

FERNÁNDEZ, Pilar, Delito de falsedad en documento público, oficial y mercantil, Madrid: Marcial Pons, 1996.

FISCHER, Thomas, Strafgesetzbuch und Nebengesetze, 64ª edición, München: Beck, 2017.

GARCÍA, María del Carmen, Falsedades documentales (en el Código Penal de 1995), Valencia: Tirant lo blanch, 1997.

GARCÍA-PABLOS, Antonio, Introducción al Derecho Penal: Instituciones, fundamentos y tendencias del Derecho Penal, vol. I, reimpresión de la $5^{\text {a }}$ edición, Madrid: Centro de Estudios Ramón Areces, 2014.

GARRIDO, Mario, Derecho penal. Parte especial, tomo IV, reimpresión de la $4^{\mathrm{a}}$ edición, Santiago: Editorial Jurídica de Chile, 2011.

GARRIDO, Mario, "El documento, en especial el público o auténtico, en el ámbito penal", Revista de Derecho de la Pontificia Universidad Católica de Valparaíso, $\mathrm{n}^{\circ} \mathrm{XXVI}$ (2005), pp. 195-200.

GERCKE, Marco; BRUNST, Phillip, Praxishandbuch Internetstrafrecht, Stuttgart: Kohlhammer, 2009.

GILLESPIE, Alisdair, Cybercrime: Key Issues and Debates, London-New York: Routledge, 2016.

GÓMEZ, Miguel, "Los Delitos Informáticos en el Derecho Español”, Informática y Derecho: Revista Iberoamericana de Derecho Informático, $\mathrm{n}^{\circ} 4$ (1994), pp. 481 496.

GONZÁLEZ, Juan José, "Protección penal de sistemas, elementos, datos, documentos y programas informáticos", Revista Electrónica de Ciencia Penal y Criminología, $\mathrm{n}^{\circ}$ 01-14 (1999), en: http://criminet.ugr.es/recpc/recpc_01-14.html [visitado el 10.11.2017].

GUZMÁN, José Luis, "Defensas: Capítulo V. Falsedad documental y supresión de actuaciones en expedientes judiciales", en: GUZMÁN, José Luis, Estudios y defensas penales, $3^{\mathrm{a}}$ edición aumentada, Santiago: Legal Publishing, 2009, pp. 511523.

GUZMÁN, José Luis, "Evaluación y racionalización de la reforma de los delitos contra la libertad sexual”, Revista de Ciencias Sociales, no 68 (2016), pp. 105-136. 
HERNÁNDEZ, Héctor, "Tratamiento de la criminalidad informática en el derecho penal chileno. Diagnóstico y propuestas", Informe solicitado por la División Jurídica del Ministerio de Justicia (inédito), 2001, pp. 1-26.

HERNÁNDEZ, Héctor, "Uso indebido de tarjetas falsificadas o sustraídas y de sus claves", Revista Política Criminal, $\mathrm{n}^{\circ} 5$ (2008), pp. 1-38, en: http://www.politicacriminal.cl/n_05/A_2_5.pdf [visitado el 10.11.2017].

HUERTA, Marcelo; LÍBANO, Claudio, Delitos informáticos, Santiago: Editorial Jurídica ConoSur, 1996.

JIJENA, Renato, "Delitos informáticos, Internet y Derecho", en: RODRÍGUEZ, Luis (coord.), Delito, pena y proceso. Libro homenaje a la memoria del profesor Tito Solari Peralta, Santiago: Editorial Jurídica de Chile, 2008, pp. 145-162.

KIEFER, Mariana, "Daño informático", en: DUPUY, Daniela (dir.), Cibercrimen, Montevideo-Buenos Aires: B de f, 2016, pp. 313-344.

KOCHHEIM, Dieter, Cybercrime und Strafrecht in der Informations- und Kommunikationstechnik, München: Beck, 2015.

LABATUT, Gustavo, Derecho penal, tomo II, $7^{\mathrm{a}}$ edición actualizada por el profesor Julio Zenteno Vargas, Santiago: Editorial Jurídica de Chile, 2000.

LONDOÑO, Fernando, "Los Delitos Informáticos en el Proyecto de Reforma en Actual Trámite Parlamentario", Revista Chilena de Derecho Informático, nº 4 (2004), pp. 171-190.

MALEK, Klaus; POPP, Andreas, Strafsachen im Internet, $2^{\text {a }}$ edición revisada, Heidelberg: C. F. Müller, 2015.

MARTÍNEZ-PEREDA, José Manuel, "Las falsedades en documentos oficiales”, en: Las falsedades documentales. Libro homenaje a Enrique Ruiz Vadillo, Granada: Comares, 1994, pp. 77-120.

MATA Y MARTÍN, Ricardo, "Capítulo IV. Perspectivas sobre la protección penal del software", en: ROMEO, Carlos (coord.), El cibercrimen: nuevos retos jurídico penales, nuevas respuestas político-criminales, Granada: Comares, 2006, pp. 97 152.

MATUS, Jean Pierre; RAMÍREZ, María Cecilia, Lecciones de Derecho Penal Chileno, Parte Especial, $3^{\mathrm{a}}$ edición, tomo II, Santiago: Thomson Reuters, 2015.

MAYER LUX, Laura, "El bien jurídico protegido en los delitos informáticos", Revista Chilena de Derecho, vol. 44, $\mathrm{n}^{\circ} 1$ (2017), pp. 235-260.

MENESES, Claudio, El documento público como medio de prueba en el proceso civil chileno, Santiago: Thomson Reuters, 2017.

MIRÓ, Fernando, El cibercrimen: Fenomenología y criminología de la delincuencia en el ciberespacio, Madrid: Marcial Pons, 2012.

MORÓN, Esther, "Delitos contra la confidencialidad, integridad y disponibilidad de datos y sistemas informáticos", en: Cuadernos Penales José María Lidón, $n^{\circ}$ 4, Bilbao: Universidad de Deusto, 2007, pp. 85-128.

MOSCOSO, Romina, "La Ley 19.223 en general y el delito de hacking en particular", Revista Chilena de Derecho y Tecnología, vol. 3, n ${ }^{\circ} 1$ (2014), pp. 11-78.

MUÑOZ CONDE, Francisco, Derecho penal parte especial, $20^{\mathrm{a}}$ edición, Valencia: Tirant lo blanch, 2015.

ORTIZ, Pedro, "La falsificación de instrumento privado", Revista de Ciencias Penales, tomo VII (1944), pp. 207-214. 
OSSANDÓN, Magdalena, La formulación de tipos penales: Valoración crítica de los Instrumentos de Técnica Legislativa, Santiago: Editorial Jurídica de Chile, 2009.

PASTOR, Nuria, Los delitos de posesión y los delitos de estatus: una aproximación político — criminal y dogmática, Barcelona: Atelier, 2005.

PÉREZ, Gabriel, Delitos de falsedad documental, Buenos Aires: Hammurabi, 2013.

POLITOFF, Sergio; MATUS, Jean Pierre; RAMÍREZ, María Cecilia, Lecciones de

Derecho penal chileno. Parte especial, reimpresión de la $2^{\text {a }}$ edición, Santiago:

Editorial Jurídica de Chile, 2012.

PUPPE, Ingeborg, "§ 274”, en: KINDHÄUSER, Urs; NEUMANN, Ulfrid; PAEFFGEN, Hans-Ullrich (edits.), Nomos Kommentar, Strafgesetzbuch, tomo 3, 4a edición, Baden-Baden: Nomos, 2013, pp. 1032-1040.

QUERALT, Joan, "La falsedad documental: una aporía casacional”, en: LÓPEZ, Jacobo; ZUGALDÍA, José (coords.), Dogmática y ley penal. Libro homenaje a Enrique Bacigalupo, tomo II, Barcelona: Marcial Pons, 2004, pp. 1121-1152.

QUINTANO, Antonio, La falsedad documental, Madrid: Reus, 1952.

RIQUERT, Marcelo, Delincuencia informática en Argentina y el Mercosur, Buenos Aires: Ediar, 2009.

RODRÍGUEZ, Luis; OSSANDÓN, Magdalena, Delitos contra la función pública, reimpresión de la $2^{\text {a }}$ edición, Santiago: Editorial Jurídica de Chile, 2011.

ROJAS, Luis Emilio, "Falsedad documental como delito de engaño", Revista Chilena de Derecho, vol. 41, n 2 (2014), pp. 523-554.

ROJAS, Luis Emilio, Teoría funcionalista de la falsedad documental, Madrid: Marcial Pons, 2017.

ROMEO, Carlos, "De los delitos informáticos al cibercrimen. Una aproximación conceptual y político_criminal”, en: ROMEO, Carlos (coord.), El cibercrimen: nuevos retos jurídico-penales, nuevas respuestas político-criminales, Granada: Comares, 2006, pp. $1-42$.

ROXIN, Claus, "Los delitos de tenencia", en: SCHROEDER, Friedrich-Christian; ECKSTEIN, Ken; FALCONE, Andrés (coords.), Delitos de posesión o tenencia, Buenos Aires: Ad hoc, 2016, pp. 143-163.

SALVADORI, Ivan, "La regulación de los daños informáticos en el código penal italiano", Revista de Internet, Derecho y Política, n 16 (2013), pp. 44-60.

STRUENSEE, Eberhard, "Besitzdelikte", en: SAMSON, Erich (edit.), Festschrift für Gerald Grünwald zum siebzigsten Geburtstag, Baden-Baden: Nomos, 1999, pp. 713-729.

VILLACAMPA, Carolina, La falsedad documental: análisis jurídico penal, Barcelona: Cedecs, 1999.

\section{Documentos citados}

"Anteproyecto de Código Penal Chileno de 2005, elaborado por la Comisión Foro Penal", Revista Política Criminal, no 1, pp. 1-92.

Proyecto de Código Penal del año 2014, Boletín n 9274-07, ingresado el 10 de marzo de 2014. 